\title{
Anti-Citrullinated Protein Antibodies in Patients with Rheumatoid Arthritis: Biological Effects and Mechanisms of Immunopathogenesis
}

\author{
Chao-Yi Wu ${ }^{1,2}$, Huang-Yu Yang ${ }^{2,3}$ and Jenn-Haung Lai ${ }^{4,5, *(\mathbb{D}}$ \\ 1 Division of Allergy, Asthma, and Rheumatology, Department of Pediatrics, Chang Gung Memorial Hospital, \\ Taoyuan 333, Taiwan; joywucgu@hotmail.com \\ 2 Chang Gung University, College of Medicine, Taoyuan 333, Taiwan; hyyang01@gmail.com \\ 3 Department of Nephrology, Chang Gung Memorial Hospital, Taoyuan 333, Taiwan \\ 4 Division of Allergy, Immunology, and Rheumatology, Department of Internal Medicine, Chang Gung \\ Memorial Hospital, Chang Gung University, Taoyuan 333, Taiwan \\ 5 Graduate Institute of Medical Science, National Defense Medical Center, Taipei 114, Taiwan \\ * Correspondence: laiandho@gmail.com; Tel.: +886-2-8791-8382; Fax: +886-2-8791-8382
}

Received: 15 May 2020; Accepted: 2 June 2020; Published: 4 June 2020

\begin{abstract}
Individuals with high anti-citrullinated protein antibody (ACPA) titers have an increased risk of developing rheumatoid arthritis (RA). Although our knowledge of the generation and production of ACPAs has continuously advanced during the past decade, our understanding on the pathogenic mechanisms of how ACPAs interact with immune cells to trigger articular inflammation is relatively limited. Citrullination disorders drive the generation and maintenance of ACPAs, with profound clinical significance in patients with RA. The loss of tolerance to citrullinated proteins, however, is essential for ACPAs to exert their pathogenicity. N-linked glycosylation, cross-reactivity and the structural interactions of ACPAs with their citrullinated antigens further direct their biological functions. Although questions remain in the pathogenicity of ACPAs acting as agonists for a receptor-mediated response, immune complex (IC) formation, complement system activation, crystallizable fragment gamma receptor $(\mathrm{F} c \gamma \mathrm{R})$ activation, cross-reactivity to joint cartilage and neutrophil extracellular trap (NET)-related mechanisms have all been suggested recently. This paper presents a critical review of the characteristics and possible biological effects and mechanisms of the immunopathogenesis of ACPAs in patients with RA.
\end{abstract}

Keywords: anti-citrullinated protein antibodies; rheumatoid arthritis; pathogenesis

\section{Introduction: Overview of ACPAs in Patients with Rheumatoid Arthritis}

Rheumatoid arthritis (RA) is a systemic chronic inflammatory disease characterized by synovial inflammation and joint destruction. It affects $0.5 \%-1 \%$ of the population worldwide, and can conceivably lead to joint destruction and disability [1]. As part of the 2010 American College of Rheumatology/European League Against Rheumatism RA classification criteria, autoantibodies, including rheumatoid factor (RF) and anti-citrullinated peptide antibodies (ACPAs), are hallmarks of the disease [2]. ACPAs, compared to the classic and well-known RA-specific antibody RF, are detected in approximately two-thirds of RA patients, with a superb diagnostic specificity of up to $90 \%$ [3,4]. Even though $1 \%-3 \%$ of the healthy populations may also test positive for ACPAs, the levels are mostly in the lower range, and react with a narrow spectrum of citrullinated antigens with different avidities compared to those found in RA [5-8]. The presence of ACPAs has been shown to precede the onset of clinical symptoms by many years, and is consistently related to a more severe and erosive phenotype [9-12]. Despite greater disease severity, radiographic joint damage and poorer 
remission rates $[13,14]$, the presence of ACPAs is also associated with extra-articular manifestations, including pulmonary and cardiovascular involvement $[15,16]$. Clinically, ACPA status is also relevant for treatment decisions in patients with RA. Accumulating evidence suggests that ACPA seropositivity predicts a good response to rituximab [17-19], but is not an ideal biomarker to monitor the efficacy of methotrexate or tumor necrosis factor (TNF) inhibitors [20,21]. Due to their high specificity and excellent clinical correlations, ACPAs have become the autoantibodies of attention in the field of RA research in recent decades [22].

The history of ACPAs can be traced back to 1964, when anti-perinuclear factors were discovered within the sera of RA patients, and later characterized by their reactivity toward citrullinated peptides in 1998 [23]. Since the discovery of ACPAs more than half a century ago, our understanding of their mechanisms of origin and generation has progressed, along with their clinical significance. Recently, the 'mucosal origin hypothesis' proposed an environmental trigger in addition to a susceptible genetic background in the development of RA [24]. The revolutionary model for RA development stated that a 'second hit' may be required beyond the presence of ACPAs in disease induction [25]. As cigarette smoking and mucosal pathogens are both capable of activating peptidyl arginine deiminase (PAD) and generating citrullinated neoantigens [26-29], the accumulation of citrullinated antigens and strong immune triggers provided by the virulent agents within the smoke or microbe can possibly attract and activate dendritic cells and B cells for sequential antibody production [25]. With the help of human leukocyte antigen (HLA) molecules, interactions among antigen-specific B cells, $T$ cells and antigen presenting cells (APCs) in the secondary lymphoid organs further promote the maturation of ACPAs [25].

In recent years, our understanding on the generation of ACPAs has progressed significantly, along with the notion of their clinical significance [25,30]. The possible biological effects and pathogenic mechanisms of how ACPAs interact with cells within the synovial space and induce articular inflammation, however, are relatively limited. The joint space among patients with RA is known to be rich with infiltrated immune cells, including lymphocytes, macrophages and neutrophils [1]. The activation of residential fibroblasts and osteoclasts may also contribute to the pathogenesis of RA. Below, we review the latest evidence, discuss several important characteristics of ACPAs, and focus on the interaction between ACPAs and active players in the development of RA.

\section{Characteristics of ACPAs in RA}

Antibodies are Y-shaped proteins produced by plasma cells which recognize unique antigens, and are subdivided into different isotypes according to their crystallizable fragment $(\mathrm{Fc})$ region. The isotype and specificity critically determine an antibody's immune function and the target it interacts with. While ACPAs and RF are the two leading autoantibodies discovered within patients with seropositive RA and frequently co-occur, these two antibodies exhibit many distinct features and different characteristics which critically determine their roles of pathogenesis. Some distinct characteristics of ACPA, in comparison with RF, are summarized in Table 1, suggesting that the development of these specific autoantibodies from underlying B cell subsets may be through different mechanisms [31]. Compared to IgM-predominant RF, both IgG and IgA are the leading isotypes for ACPAs. Many repeated germinal center reactions, with the help of CD4 T cells, are crucial for the affinity maturation of ACPAs; however, RF-positive B cells only go through a few rounds of germinal center reactions. Furthermore, while all immunoglobulins belong to the glycoprotein family, the extensive $\mathrm{N}$-glycosylation discovered in ACPAs plays an important role in altering immunoglobulin functions. Herein, we discuss the important characteristics of ACPAs which critically dictate their role in the immunopathogenesis of RA. 
Table 1. The distinct characteristics of ACPA, in comparison with RF [31].

\begin{tabular}{|c|c|c|}
\hline & ACPA & RF \\
\hline Isotypes & mainly IgG and IgA & $\operatorname{Ig} M>\operatorname{Ig} G>\operatorname{Ig} A$ \\
\hline Clinical association & specific for RA & $\begin{array}{c}\text { common in various autoimmune } \\
\text { diseases }\end{array}$ \\
\hline N-glycosylation & extensive & limited \\
\hline Germinal center reactions & repeated & limited \\
\hline Somatic hypermutations & extensive & limited \\
\hline Class switching & extensive & limited \\
\hline B cell activation & $\mathrm{T}$ cell dependent & $\begin{array}{l}\mathrm{T} \text { cell dependent and/or } \mathrm{T} \text { cell } \\
\text { independent }\end{array}$ \\
\hline Producing plasma cells & long lived plasma cells & $\begin{array}{l}\text { short lived plasma cells and/or } \\
\text { plasmablasts }\end{array}$ \\
\hline
\end{tabular}

\subsection{ACPA Isotypes}

The Fc region of ACPAs is crucial in actively contributing to the pathogenesis of RA [32,33]. Unlike the isotypes of RF, where various isotypes ( $\operatorname{IgM}>\operatorname{IgA}>\operatorname{IgG}$ ) were found [31], the enrichment of $\operatorname{IgG}$ and IgA isotypes and an early increase in IgG, particularly IgG1 subclasses, frequency and concentration, were found to dominate in the serum of patients with RA, or to precede the development of the disease [31,34-36]. A predominant production of IgA-isotype ACPAs in preclinical samples was also noted among the subjects at risk for RA [37,38]. Interestingly, with its association with the concurrent presence of neutrophils and macrophages, as well as endogenous neutrophil extracellular trap (NET) formation in the sputum, the production of local ACPA IgA was linked to mucosal inflammation [39]. Furthermore, a markedly increased number of IgA-positive plasmablasts, compared to IgG-positive plasmablasts, in at-risk individuals was also observed in comparison with those with early RA and others [40]. IgG is the most important immunoglobulin triggering macrophage activation through Fc gamma receptor $(\mathrm{Fc} \gamma \mathrm{R})$ engagement, and IgA potently activates neutrophils and is the antibody that dominates in the mucous membranes [41]. The fact that IgG and IgA are the main isotypes of ACPAs in patients with RA not only signals their potential mechanism of action, but also supports the 'mucosal origin hypothesis', which has recently been proposed [24].

\subsection{ACPA Specificity and Avidity}

ACPAs consist of a group of antibodies which react with a variety of citrullinated antigens generated through the posttranslational modification of arginine through PADs; namely, citrullination [42,43]. Over the years, various protein candidates for citrullination, such as keratin, fibrinogen, vimentin, fibronectin and $\alpha$-enolase, have been identified. In fact, the term 'RA citrullinome' was introduced recently, referring to the collection of more than 100 citrullinated proteins identified in the serum and synovial fluid of RA patients [44-48]. Although considerable efforts have been devoted by scientists in recent years, no single citrullinated antigen stood out as a dominant epitope for ACPAs [49]. Evidence suggests that it is likely the process of citrullination, rather than any particular citrullinated antigen itself, that drives the autoimmune response in RA [49]. Moreover, as ACPAs are also known to cross-react with peptides undergoing other posttranscriptional modifications, such as carbamylation and acetylation $[50,51]$, the spectrum of epitopes recognized by ACPAs is further extended.

The fine specificity of ACPAs is critical for these antibodies to cause immunopathology. It has been shown that ACPAs isolated from patients with RA not only react with a broad spectrum of citrullinated peptides with different avidities, but also vary from patient to patient with heterogenicity [6-8]. Although the broad reactivity of ACPAs may be partially explained by overlapping reactivity, $\mathrm{Li}$ and colleagues discovered that, while two-thirds of ACPAs derived from plasmablasts in patients with RA cross-reacted with different tested epitopes, one-third of them recognized only monotargets, including citrullinated fibrinogen, endolase and vimentin [8]. Recently, Ge and colleagues performed a series of crystal structure analyses via X-ray crystallography, and proposed a model to explain 
the specificity and function of ACPAs [52,53]. As studies demonstrated that several types of structural interactions exist between ACPAs and their citrullinated antigens, the citrulline side-chain-specific 'promiscuous ACPAs', the major population of autoantibodies in the sera of RA patients, may not preserve a functional role [52]. On the other hand, the 'private ACPAs' interacting with citrulline and proximal amino acid side chains and specifically recognizing or 'cross-reacting' with citrullinated epitopes on joint proteins exhibit an arthritogenic role [52]. As an example, through structural studies, Ge and others recently demonstrated that ACPAs could induce the proteoglycan depletion of cartilage and lead to severe arthritis through the cross-reactivity of collagen-type-II-specific ACPAs to joint cartilage [54].

Furthermore, the diversity and avidity of ACPAs toward citrullinated peptides are not fixed, but rather change and evolve with time. Van der Woude and colleagues observed an increase in the amount of citrullinated epitopes recognized by autoantibodies isolated from the sera of pre-RA patients [55]. They showed that the ACPAs isolated from those who were later diagnosed with RA recognized considerably more citrullinated targets than the ACPAs isolated from those who were not [55]. A similar phenomenon was also reported recently by Kongpachith and colleagues, utilizing various citrullinated peptide tetramers [56]. They demonstrated that somatic hypermutations accumulated during affinity maturation by clonally related B cells altered the antibody paratope to mediate 'epitope spreading' and the polyreactivity of the ACPA response in RA [56]. In other words, extensive ACPA specificity in RA is derived from a limited repertoire of continuously evolving citrulline-multispecific B cells via constant antigen exposure [57-60]. In this respect, a vigorous antigen-specific CD4+ T cell response with repetitive germinal center selection would be expected, and indeed has been shown to be the case, for ACPA development soon afterwards [60].

\subsection{N-Linked Glycosylation of ACPA}

$\mathrm{N}$-linked glycosylation is the attachment of glycans or polysaccharides to a protein that is important for both its structure and function [61]. Compared to total IgG, where the glycosylation of the antigen-binding fragment $(F a b)$ was estimated to be approximately $14 \%$ [62], over $80 \%$ of the citrulline-reactive B cells were found to contain glycosylation sites in the sequences of their variable domains [63]. This is consistent with the protein level, where more than 90\% of ACPAs were found to carry glycans in their variable domain [64].

The N-linked glycosylation of $F a b$ has been shown to be critical in predicting the development of RA [65]. According to Rombouts et al., there was a 10-20 kDa higher molecular mass of the autoreactive ACPAs of RA patients, which resulted from the high frequency of $\mathrm{N}$-glycans in the variable domains [66]. The data indicated that the N-glycosylation sites in ACPA variable domains were introduced by somatic hypermutation, and suggested that ACPA hyperglycosylation confers a selective advantage to ACPA-producing B cells [66]. Similar findings were also supported by other studies suggesting that extensive glycosylation of the IgG ACPA V domain predisposed individuals to the development of RA in a subset of first-degree relatives of indigenous North American RA patients [65]. Interestingly, the sialylation of anti-type II collagen antibodies, including ACPAs, has been found to attenuate arthritogenic activity and suppress the development of arthritis in an experimental murine model [67]. Although Lloyd and colleagues later demonstrated that the sialyation of Fab glycans did not influence antigen binding, the negative charge resulting from sialyation offered selective advantages for ACPA-specific B cells beyond N-linked glycosylation in the variable domain [68]. Together, these data implied not only the importance of N-glycosylation in ACPAs but also the potential pathogenic process directed by the ACPA variable region.

Similar to that of the variable regions, the glycosylation of the $\mathrm{F}_{\mathrm{C}}$ fragment is also a unique feature of ACPAs $[34,69]$. Specifically, antibodies carrying glycans in the Fc portion lack galactose residues and display an enhanced ability to activate the immune system [70,71]. Moreover, in comparison with the pool of serum antibodies, the Fc fragment of ACPAs was generally increased in core fucosylation and decreased in galactosylation and sialylation $[34,69]$. These glycosylation modifications are important for the molecular interactions and functions of ACPAs [72-74] 


\subsection{Synergism between ACPAs and RF through Immune Complex Formation}

ICs formed by the conjunction of ACPAs and citrullinated proteins followed by complement and Fc $\gamma \mathrm{R}$ activation are considered to play a role in ACPA immunopathogenesis [32,33]. Compellingly, when working in conjunction with RF, a synergistic effect is elicited. Partly contributed by the multivalent binding originating from the conformational change in the IgG glycosylation motifs, ACPAs have been documented to work in conjunction with RF to elicit a synergic effect via IC formation and to enhance sequential inflammation [72-74]. The synergistic effects of ACPAs and RF in IC formation will be discussed in more detail in the following sections.

\section{Immunopathogenesis of ACPAs in RA}

Various studies have documented the induction of ACPAs and the arthritogenicity of ACPAs in different murine models [75,76]. The presence of ACPAs in patients with more destructive RA and the accumulation of citrullinated peptides in the rheumatoid joints further suggests the possible role of ACPAs in RA pathogenesis [9-11,44-48]. As various immune cells and local tissues are directly involved in the process of joint inflammation, autoantigens are a key sustaining element in autoimmune diseases which fuel the subsequent immune responses. Herein, we approach the issue from the generation of citrullinated antigens and the interactions of ACPAs with RA-related immune players, as well as synovial structural tissues. A summary of the immunopathogenesis of ACPAs within the joint space is depicted in Figure 1.

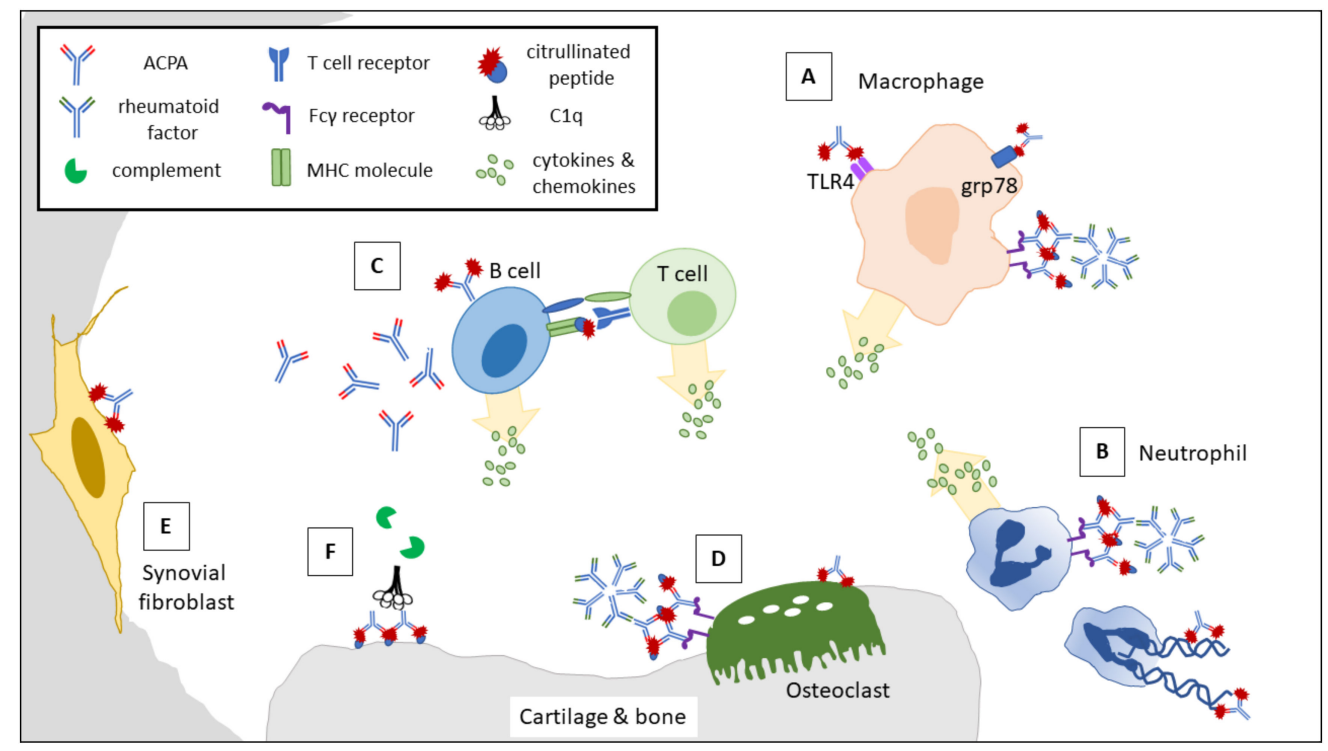

Figure 1. ACPA-related RA immunopathogenesis. ACPAs activate macrophages via IC formation and agonistic activity. They bind to the grp78 protein and TLR4 on the cell surface to elicit an inflammatory response. Additionally, through the binding of ICs and Fc $\gamma$ R, proinflammatory cytokines and M-CSF are released (A). Neutrophils and ACPAs interact in a self-perpetuating manner. As NETosis releases massive amounts of citrullinated antigens to drive ACPA production, the ACPA formation of ICs promotes further neutrophil netting and the release of degradative enzymes and reactive oxygen species upon binding with Fc $\gamma \mathrm{R}(\mathrm{B})$. Autoreactive B cells baring surface ACPAs can serve as APCs to promote citrulline-specific $\mathrm{T}$ cell maturation/differentiation and secrete various proinflammatory cytokines (C). Direct ACPA targeting enhances osteoclast differentiation. The binding of ICs via Fc $\gamma \mathrm{R}$ activates osteoclasts and promotes proinflammatory cytokine production (D). ACPAs interact with citrullinated cellular proteins and enhance fibroblast migration (E). Complement activation takes place via both the classical pathway and the alternative pathway. ACPAs also cross-react with type II collagen within joint cartilage, resulting in joint destruction (F). ACPAs, anti-citrullinated peptide antibodies; RA, rheumatoid arthritis; TLR4, Toll-like receptor 4; Fc $\gamma$ R, Fc gamma receptors; IC, immune complex; C5a, complement 5a; M-CSF, macrophage colony-stimulating factor. 


\subsection{Dysregulated Citrullination Fuels the Production of Citrullinated Neoantigens for ACPA Targeting}

Although citrullinated proteins are known as targets for ACPAs and are potentially active players in RA pathogenesis, citrullination itself is not a pathogenic but a physiological process that is involved in brain development, apoptosis, epidermal differentiation and chromatin modulation [77]. Citrullination is a calcium-dependent process and requires a reducing environment for efficient activity $[78,79]$. The products from PAD enzymatic reactions have increased protein hydrophobicity and altered protein physical function because of changes in intra- and intermolecular interactions [80-82]. However, when excessive citrullination occurs beyond physiological regulation, the resulting citrullinated peptides may potentially become neoantigens to fuel sequential ACPA generation and serve as binding targets $[48,83]$.

The accumulation of intracellular and extracellular citrullinated proteins in rheumatoid joints suggests a citrullination disorder in patients with RA [44-48]. Functional haplotypes of PAD4, one of the enriched PADs discovered in the joints of RA patients $[84,85]$, were also reported to be associated with RA among subjects with different genetic backgrounds $[86,87]$. In addition, part of the factors, such as environmental stimuli and cell death pathways of various forms, have been suggested to promote the generation of citrullinated autoantigens in RA, as discussed below.

\subsubsection{Environmental Factors and ACPA Production}

Tobacco smoking and local microbial virulence are the two leading environmental risk factors triggering the generation of ACPA in patients with RA [88,89]. Smoking was also found to be linked to higher PAD2 expression, leading to increased citrullination in patients' lungs [26]. Such an effect provides an opportunity for the exposure of neo-antigens in patients' lungs for residential APCs recognition and presentation for sequential antibody production. Next, the strong association of smoking with ACPA positivity in cases with shared epitope (SE) implies a role of CD4 T cells in the RA pathogenesis [90]. Local accumulation of citrullinated antigens and strong immune triggers provided by the virulent agents within the smoke can also possibly attract and activate dendritic cells and B cells for sequential antibody production.

The infection by periodontitis-causing bacteria, such as Porphyromomas gingivalis ( $P$. gingivalis) and Aggregatibacter actinomycetemcomitans $(A a)$, as well as intestinal microbiota, likely contributes to ACPA-associated RA pathogenesis [91-95]. The bacterial pore-forming virulence and calcium ionophores, such as ionomycin and calcimycin from Streptomyces species and leukotoxin A from $A a$, are important in triggering calcium influx and generating non-tolerized neo-citrullinated epitopes [27-29]. Citrullination in P. gingivalis-related periodontitis works through different mechanisms. P. gingivalis is a pathogen capable of citrullinating peptides into a unique pattern due to the expression of its own PAD [96]. However, due to the failure in surveying the actual recognizability of $P$. gingivalis PAD-citrullinated peptides by human ACPA, the definitive conclusions as to periodontitis induced by P. gingivalis in ACPA-associated RA pathogenesis cannot be reached according to the currently available data [91]. Interestingly, De Aquino and others have shown that the arthritis induced by P. gingivalis is largely dependent on the expansion and activation of Th17, possibly through TLRs and IL-1 [97,98]. Through IL-17Ra signaling, neutrophils infiltrated and aggravated articular inflammation and resulted in local articular destruction [97].

\subsubsection{Cellular Death Pathways and ACPA Production}

The activation of intracellular PADs, the leakage of transiently active PADs into the surroundings and the generation of de novo citrullinated proteins are some of the possible mechanisms related to cellular death pathways [27,99-101]. Specifically, autophagy has been shown to lead to the citrullination of $\alpha$-enolase and vimentin in monocytes and fibroblast-like synoviocytes [100,102]. These citrullinated proteins are known targets for ACPAs, and the level of autophagy markers is well correlated with the titer of ACPAs [100]. Such a notion is also supported by the synchronized reduction of autophagy and levels of citrullinated proteins in patients with RA upon etanercept treatment [103]. In addition, 
although it is still unclear whether NETosis creates pathogenic citrullination or merely redistributes an existing citrullinome, the release of citrullinated autoantigens extracellularly has been demonstrated to trigger ACPA-associated experimental arthritis $[48,99,104]$. As previously discussed, bacterial virulence also contributes to cellular damage and results in excessive citrullination [27-29]. Collectively, cell death pathways including autophagy, NETosis and a distinct neutrophil death, namely leukotoxic hypercitrullination, have been implicated in the generation of citrullinated auto-antigens and inducing the development of ACPA in susceptible subjects [105].

To date, the significance of the RA citrullinome in the generation of ACPAs and RA pathogenesis has not yet been fully recognized. 'Exaggerated citrullination of physiologic substrates' or the 'citrullination of non-physiological targets' have been suspected to drive the generation and maintenance of ACPAs. Notably, Andrade and others have found a unique pattern of citrullination over a variety of different proteins in cells isolated from RA patients' synovial fluid, which they described as hypercitrullination [48]. If nonselective citrullination unwittingly develops due to uncontrolled PAD activity, neo-citrullinated proteins that are not previously tolerized by the immune system may likely trigger an autoimmune response. On the other hand, overactive PADs may target novel sites for reactions and generate neoepitopes by accident. To date, five PADs (PAD1-4 and 6) have been identified in humans. Considering the enrichment of PAD2 and PAD4 in RA synovial tissue and fluid, these two PADs have gained the most attention in RA research $[84,85,106]$. Previous studies have shown that, compared to PAD4, PAD2 plays a dominant role in fibrinogen citrullination [107]. When catalyzed by PAD4, however, a distinctive and partially citrullinated fibrinogen became preferentially recognized by ACPAs [83]. Collectively, current evidence suggests that dysregulated citrullination may drive the generation of neoantigens for ACPA recognition and targeting in susceptible individuals prone to RA.

\subsection{Interactions between ACPAs and RA-Related Immune Cells and Mediators}

\subsubsection{ACPAs Activate Macrophages via IC Formation and Agonistic Activity to Elicit} Proinflammatory Cytokine Production

Routinely residing in the synovial space despite inflammation, resting macrophages are potent immune effectors that can robustly promote inflammatory responses and result in joint destruction upon stimulation [108]. ACPAs have been shown to directly interact with surface-expressed citrullinated glucose-regulated protein 78 in RA monocytes with its Fab variable domain $[109,110]$. Lu and colleagues showed that ACPAs selectively activate extracellular signal-regulated kinases (ERK)1/2 and c-Jun $\mathrm{N}$-terminal kinase (JNK) signaling pathways to activate nuclear factor-kappaB (NF- $\mathrm{kB}$ ) and promote the production of tumor necrosis factor-alpha (TNF- $\alpha$ ) upon binding $[109,110]$. Compellingly, despite the direct targeting of ACPAs to citrullinated surface protein on monocytes through an unknown interaction, a follow-up study from the same research group documented that ACPAs are also capable of suppressing let-7a, a microRNA, expression in monocytes from RA patients and facilitating inflammatory responses through the JNK and NF- $\mathrm{kB}$ pathways [111].

Recently, Sokolove and others have shown with murine and human macrophages that ACPAs against citrullinated fibrinogen elicited higher TNF production than native antibodies [32]. They discovered that ACPAs alone, specifically anti-citrullinated fibrinogen, stimulate macrophages in a Toll-like receptor (TLR)4- and MyD88-dependent manner [32]. Alternatively, when ACPAs were incorporated into the IC, they stimulated macrophages via dual engagement of TLR4/MyD88 and Fc $\gamma R$ for the production of TNF- $\alpha$ [32]. Precisely, the binding of ICs to Fc $\gamma$ Rs on macrophages was not via Fc $\gamma$ RI or Fc $\gamma$ RIII [112]. Documented by Clavel and others, their data suggested that the cross-linking of Fc $\gamma$ RIIa on macrophages upon IC binding strongly activated the signal for cytokine release [112].

Regardless of the diverse interactions, in the presence of macrophage colony-stimulating factor and RF, particularly IgM and IgA isotypes, the ability of ICs to produce proinflammatory cytokines in the synovial membrane appears to be greatly enhanced [72-74,113]. The robust secretion of proinflammatory cytokines, particularly TNF- $\alpha$, by macrophages upon activation strongly promotes inflammatory responses and results in joint destruction [108]. In detail, TNF- $\alpha$ works as an 
autocrine stimulator for myeloid cells, and serves as a potent paracrine inducer for the production of proinflammatory cytokines critical for lymphocyte proliferation and differentiation [114]. It induces the synthesis of collagenase and prostaglandins, as well as IL-8, by synovial fibroblasts to promote joint cartilage degradation and stimulate more effector cell migration into the synovial spaces [114]. Additionally, its ability to stimulate the expression of endothelial-cell adhesion molecules, suppress regulatory $\mathrm{T}$ cells, promote angiogenesis and induce pain sensation are also important mechanisms related to the pathological profiling of RA $[108,114]$.

3.2.2. ACPA-Forming ICs Promote NETosis and the Release of Degradative Enzymes and Reactive Oxygen Species upon Binding with Fc $\gamma \mathrm{R}$

The ICs formed within the synovial space and those deposited on the cartilage articular surface were important mediators for neutrophil activation. As defects of Fc $\gamma$ Rs largely attenuate neutrophil activation in the presence of ICs, similar but different from those of macrophages, the engagement of ICs with Fc $\gamma$ Rs, particularly Fc $\gamma$ RI and Fc $\gamma$ RIII, has been documented to trigger neutrophil activation and tissue inflammation [115-118]. Indeed, recent work put together by Kempers and others documented that ICs containing ACPA IgG1 predominately bind to activating Fc $\gamma$ RI and Fc $\gamma$ RIIIa. Perhaps because of the enhanced core fucosylation in ACPA IgG1 Fc, ICs bind better to Fc $\gamma$ RI expressed by activated neutrophils and drive disease pathogenesis in RA [119]. Specifically, following neutrophil activation, local cartilage and tissue destruction can be induced via neutrophil degranulation and the release of degradative enzymes, as well as reactive oxygen species (ROS) [120]. The activation of soluble receptors and cytokines, the inhibition of chondrocyte proliferation and the activation of synoviocyte proliferation and invasion also contribute to joint injury [120]. The generation of chemoattractants, such as IL-8 and leukotriene B4, further amplify the inflammatory process by recruiting more neutrophils to the synovium [120]. These specific characteristics of neutrophils upon activation possess a great cytotoxic potential in the pathogenesis of RA [120].

Aside from the production of degradative enzymes and the initiation of the cytokine and chemokine cascades for inflammation, the release of NETs containing extracellular fibers, chromatin, cytoplasmic proteins and granule enzymes from neutrophils provides a great source for autoantigens driving autoimmune diseases [120]. Just as Khandpur and others discovered that NETosis was enhanced in neutrophils in RA synovial fluid and systemic circulation, sera extracted from RA patients, particularly those rich in ACPAs, were shown to significantly stimulate NETosis [101]. Appealingly, a therapeutic ACPA design to alter the binding of ACPAs, by targeting citrulline at a specific position, was documented to suppress NETosis from human neutrophils triggered by disease-relevant stimuli [121]. The changes in the neutrophil response upon ACPA alteration again strengthen the importance of ACPAs in triggering NETosis [121].

NETs have been demonstrated to augment inflammatory responses in RA synovial fibroblasts, including the induction of IL-6, IL-8, chemokines and adhesion molecules [101]. Additionally, the internalization of NETs via the receptor for advanced glycosylation end products-the TLR9 pathway in synovial fibroblasts-promotes an inflammatory phenotype and the upregulation of human HLA class II [104]. While the release of NETs is a source for citrullinated autoantigens, NETosis also promotes the citrullination of proteins within the synovial space. This resulted in the autoreactivity and affinity maturation of synovial B cells. Indeed, tissue-resident B cells within the ectopic lymphoid structures were also noted to generate high-affinity ACPAs targeting NETs [122]. The accelerated activity of PADs and externalized citrullinated autoantigens upon neutrophil netting likely further fuel the production of ACPAs [101,123]. These results, together with the ability of ACPAs to promote neutrophil netting, suggest a self-perpetuating cycle that can result in profound autoimmune reactivity.

\subsubsection{ACPAs Activate Complement via the Classical and Alternative Pathways}

Many studies have validated the importance of complement activation in developing experimental antibody-mediated arthritis [124]. While RF plays a critical role in activating the complement 
system in RA, the role of ACPAs in complement fixation, specifically in the in vivo setting, remains controversial [125]. The in vitro data provided by Trouw suggests that ACPAs from patients with RA activate complement via the classical pathway in a dose-dependent manner. The alternative pathway is also involved in complement activation and sequential inflammatory processes, including the release of complement 5a (C5a) and membrane attack complex (MAC) formation [33]. The release of C5a upon complement cascade activation can lead to the chemotaxis of inflammatory cells, can increase vascular permeability, and can promote phagocytosis and the release of proinflammatory cytokines and chemokines [126]. It also amplifies inflammation and induces tissue injury via the release of free radicals and upregulates Fc $\gamma$ RIIIa to enhance the interactions between ICs and cells $[127,128]$. MAC formation, on the other hand, leads to necrotic or apoptotic cell death. This not only results in tissue injury but also boosts further citrullination $[100,102]$. As the data suggest that the incorporation of IgM or IgA RF into ACPA-forming ICs triggers the activation of complement cascades, the presence of classical pentameric IgM RF additionally makes the process more efficient [33,72].

\subsubsection{Autoreactive B Cells Baring Surface ACPAs Promote T Cell Differentiation and Secrete Proinflammatory Cytokines}

Aside from antibody production, autoreactive B cells that escape central and peripheral tolerance have also been shown to serve as APCs in promoting $\mathrm{T}$ cell maturation and differentiation into memory cells [129]. They play a critical role in the support of germinal-center-like structures (tertiary lymphoid tissues) within the inflamed synovium, and continuously fuel the autoimmune process [130]. Indeed, a proportion of $B$ cells extracted from the inflamed synovial tissue were found to react with citrullinated autoantigens $[122,131,132]$. The data also suggest that the depletion of B cells hinders the ability of $\mathrm{T}$ cells to produce interferon-gamma (IFN- $\gamma$ ) and interleukin (IL)-1 [133]. Moreover, citrulline-specific $\mathrm{T}$ cells isolated from RA patients have been shown to display predominately Th1 and Th17 phenotypes [134,135]. While Th1 cells activate macrophages to serve as APCs and are the source of various proinflammatory cytokines, such as IFN- $\gamma$, IL-2 and TNF- $\alpha$ [136,137], Th17 cells not only stimulate the production of proinflammatory cytokines, chemokines and matrix metalloproteinases (MMPs) in RA synovial fibroblasts but also promote pannus growth, osteoclastogenesis and synovial angiogenesis via IL-17 production [138].

Additionally, subsets of memory B cells have been shown to express the receptor activator of nuclear factor kappa-B ligand (RANKL) [139], a cytokine which is important for the regulation of bone homeostasis and osteoclastogenesis. Considering the ability of $\mathrm{B}$ cells to produce various proinflammatory cytokines [140], autoreactive B cells baring surface ACPAs critically support the progression of RA upon encountering their specific antigens; in this case, citrullinated peptides.

\subsection{Interactions between ACPAs and Synovial Residential Cells}

\subsubsection{Binding of ACPAs to form ICs via Fc $\gamma$ R Promotes Osteoclast Differentiation and} Proinflammatory Cytokine Production

The impact of ACPAs on osteoclasts was revealed by Harre and others upon their discovery of the strong association between ACPAs and osteoclast-mediated bone resorption markers in RA. By purifying ACPAs from patients with RA, they demonstrated that polyclonal ACPAs were capable of promoting osteoclast activation and differentiation, resulting in osteopenia and erosions in bones [141]. Considering that the effect of ACPAs can be mediated either through the direct binding of Fab to antigens or through $F_{c}$ receptor signaling, efforts have been made to clarify the underlying mechanisms and validate ACPA-mediated osteoclast activities in RA-associated symptoms.

In the past decade, several reports have displayed exciting results explaining the two prominent features of RA manifestation, joint pain and bone erosion, via direct recognition and binding of the ACPA variable region to cellular targets on osteoclasts [142,143]. Utilizing experimental murine arthritis models, studies by Wigerblad and Krishnamurthy demonstrated that ACPAs enriched from human IgG can induce pain through the release of IL-8 and promote osteoclast differentiation in a IL-8-dependent 
manner $[142,143]$. While the significance of ACPA Fab-specific binding was demonstrated by the osteoclastogenesis induced by monomeric Fab fragments created from the ACPA variable domain independent of the constant region [142,143], it caught everyone by surprise, as the following report suggested that there was in fact no binding of monoclonal ACPAs to citrullinated antigens [144-146]. Aside from the dilemma regarding the monoclonal antibody binding specificity [147,148], Sun and others reported that the binding of osteoclasts and synovial fibroblasts by ACPAs from different clonalities exhibits distinct cellular effects, including increasing osteoclast differentiation and promoting synovial fibroblast migration, suggesting that antibodies with different clonality can function differently [149].

Similar to macrophages and dendritic cells, osteoclasts also contain sufficient amounts of Fc $\gamma R$ [150]. FcRs in association with other immunomodulatory proteins on the osteoclast surface are critical for the development and function of osteoclasts [151]. As ICs containing IgG with various degrees of $\mathrm{N}$-glycosylation are known to alter the differentiation of osteoclast precursors and cell activation [152-154], the glycosylation of the ACPA Fc fragment has been shown to enhance its affinity toward $\mathrm{F} c \gamma \mathrm{R}$ and increase its capacity to induce osteoclast activation and bone erosion [154]. This effect of ACPA-related osteoclast activation is further amplified in the concomitant presence of RF, as supported by the radiographic evidence $[155,156]$.

\subsubsection{ACPAs Interact with Cellular Citrullinated Antigens and Promote Synovial Fibroblast Migration}

Synovial fibroblasts contribute to the joint architecture through the formation of the intimal lining in the synovial anatomical space [157]. Although the signature architectural distribution allows synovial fibroblasts to be exposed to many disease-specific immune mediators, its interaction with ACPAs has seldom been discussed. As discussed earlier, it has been reported that the binding of synovial fibroblasts by distinct ACPAs can lead to synovial fibroblast migration via a phosphoinositide 3-kinase-mediated mechanism [149]. Recently, Corsiero and others identified a synovial B cell-derived RA recombinant monoclonal antibody capable of reacting with citrullinated fibroblast-derived calreticulin [158]. While the pathogenic role of the latter antibody awaits further elucidation, citrullinated peptides within synovial fibroblasts likely serve as neoantigens for ACPA variable domain targeting.

\subsubsection{ACPAs Induce Joint Destruction by Cross-Reacting with Type II Collagen Fibers}

As chondrocytes are the main cellular component of articular cartilage, secreted extracellular matrix components composed of water, type II collagen, proteoglycans, non-collagenous proteins and glycoproteins make up the majority of the structure [159]. In the past, autoantibodies interacting with type II collagen in RA patients have been shown to bind with the cartilage components and antigens presented on the articular cartilage surface [160]. Recently, ACPAs were documented to cross-react with type II collagen, resulting in proteoglycan depletion and severe arthritis [54]. Although the pathogenic mechanisms were not discussed in the study [54], considering that complement activation has been shown in the antibody-cartilage surface interactions among RA patients [161], perhaps the binding of ACPAs with type II collagen induces joint inflammation and structural damage by triggering the complement cascade.

\section{Potential of Therapeutic Approaches Targeting ACPAs for Patients with RA}

Despite the clinical significance of RF and ACPAs and the current knowledge about their immunopathogenesis, no tailored treatments are specifically recommended for seropositive RA patients to date, nor for those specifically with high ACPAs [162]. Aside from the promising mechanisms discussed above, the plausibility of targeting ACPAs in RA treatment relies on the answers to the following questions. First, why is the expression of ACPAs not synchronized with the activity of RA? Accumulating evidence has also shown that the levels of ACPAs may not be ideal biomarkers to monitor the efficacy of methotrexate and TNF inhibitors in RA [20,21]. Even though rituximab and abatacept have been shown to control disease activity, the reduction in the level of ACPAs is very limited [163,164]. Moreover, upon the successful initial response to rituximab treatment, $\mathrm{ACPAs}$ do not increase in level prior to or during relapse following initial response [165]. Next, why does the disease not transfer along with placental transmission of antibodies 
during pregnancy? Although adoptive transfer of ACPAs has been demonstrated to induce arthritis in murine models [141], such a phenomenon has not been documented in humans.

Although there are no differences in C3 and C4 levels in ACPA-positive and ACPA-negative RA patients, given that complement is activated by ACPA and studies suggest a pro-inflammatory role of $\mathrm{C} 3$ in the example of anti-TNF therapy, targeting ACPA may provide potential therapeutic benefit for RA patients [125]. While the levels of ACPAs may not correlate with the severity of overall joint symptoms [166], given their pathogenic and therapeutic potential, scientists are continuously investigating new methods targeting and reducing ACPA levels. As illustrated in Figure 2, antigen-specific tolerance strategies have been successfully documented by Benham and others recently [167]. Specifically, autologous dendritic cells modified with an NF- $k B$ inhibitor were exposed to four citrullinated peptide antigens before being injected. Patients receiving such treatment showed an increased ratio of regulatory to effector $\mathrm{T}$ cells, a reduction in inflammatory cytokines and a decrease in disease activity 1 month after the procedure [167]. Furthermore, based on the success of anti-double-stranded DNA antibodies targeting peptides in systemic lupus erythematosus [168-170], scientists have identified two peptides derived from the fibrinogen $\alpha$ chain capable of disrupting ACPA binding to anti-cyclic citrullinated peptide (CCP2) [171]. Through grafting the citrullinated epitopes into a stable scaffold, the synthetic high-affinity peptide-based scavenger of ACPAs demonstrated superior stability with apparent low nanomolar affinity, which makes in vivo testing possible in the future [172]. Recently, therapeutic ACPAs specifically created to target citrulline residues in the N-terminus of histones $2 \mathrm{~A}$ and 4 have been tested in various NET-relevant diseases, including inflammatory arthritis [121]. Although not specifically designed to treat diseases resulting from ACPA overproduction, the attenuation of NETosis and sequential inflammatory processes via citrulline blockade is a useful application referenced by the pathogenic mechanisms of ACPAs. Finally, considering the importance of citrullinated disorders preceding the generation of ACPAs, PAD inhibitors were also investigated in the treatment of ACPA-positive RA [173,174]. Recently, Willis and others reported that $\mathrm{Cl}$-amidine, a pan-PAD irreversible inhibitor, partially inhibited joint inflammation in a murine arthritis model [173]. Since the safety of PAD inhibition may be a potential problem, novel compounds capable of inhibiting RA-specific, PAD4-induced citrullination are currently under investigation [174].

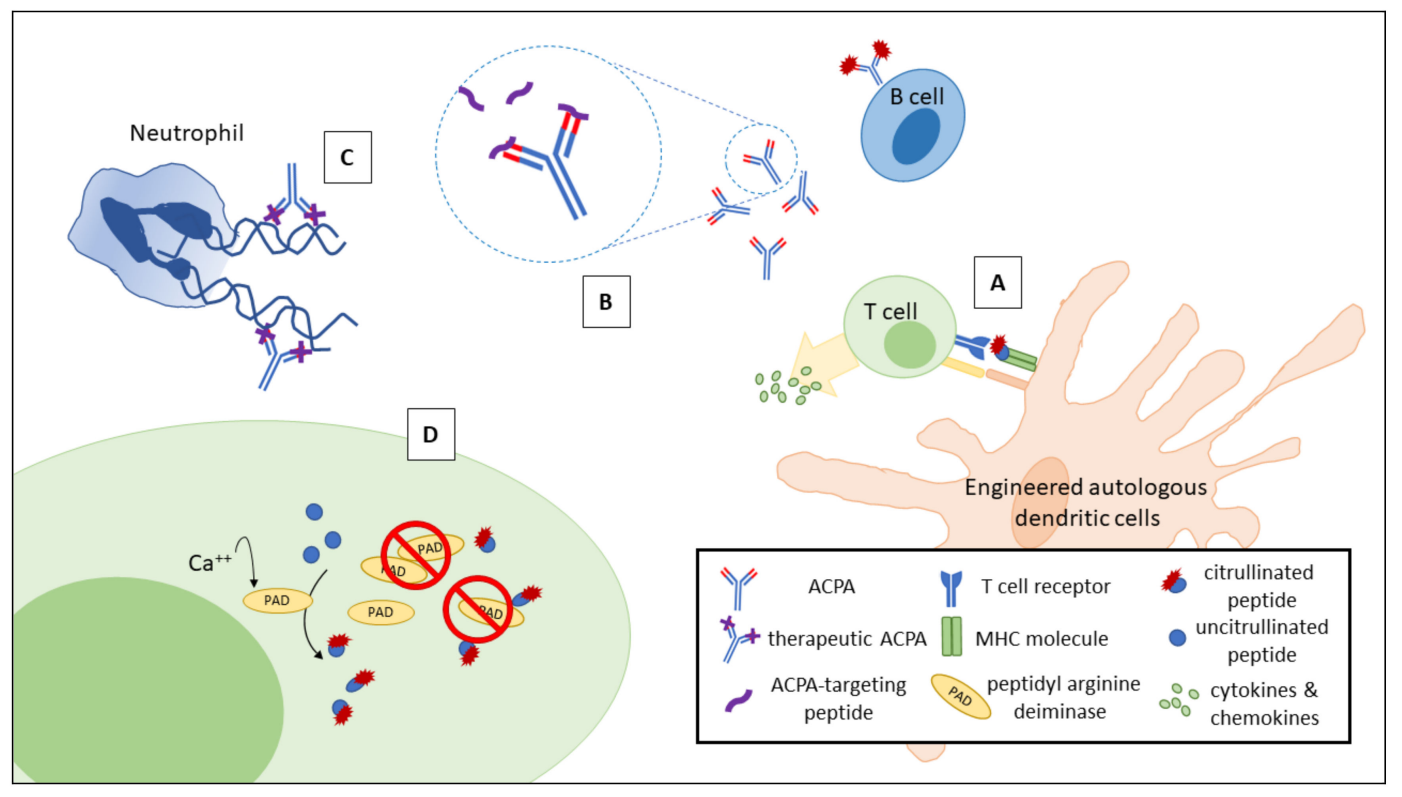

Figure 2. Potential treatment strategies for ACPA-mediated RA. Citrullinated peptide antigen-loaded 
autologous dendritic cells modified with an NF- $\mathrm{BB}$ inhibitor increase the ratio of regulatory to effector T cells (A). In (B), ACPA-targeting peptides derived from the fibrinogen $\alpha$ chain are capable of disrupting ACPA binding to its citrullinated antigens. Therapeutic ACPAs designed to interact with specific citrullinated residues can suppress NETosis and its relevant diseases (C). PAD inhibitors attenuate citrullination and reduce the generation of citrullinated neoantigens for ACPA targeting (D). ACPA, anti-citrullinated peptide antibody; RA, rheumatoid arthritis; PAD, peptidyl arginine deiminase; NF- $\mathrm{kB}$, nuclear factor kappaB.

\section{Conclusions}

The present review summarizes recent progress on the characteristics of ACPAs and the possible biological effects of ACPAs on immune cells to elicit articular inflammation. As discussed, the spectrum of the isotypes, the maturation of their specificity, $\mathrm{N}$-glycosylation and IC formation critically determine the immunopathogenicity of ACPAs. While ACPAs clearly demonstrate the potential to interact with responding cells and synovial tissues via IC formation and their agonistic activity, their role as a therapeutic target still requires more investigation. Perhaps strategies including altering antibody glycosylation [175], inducing ACPA competition with blocking aptamers, single-chain variable fragments or antibody Fab units [176], or inhibiting IC activation may be considered [177]. With the rapid advancement in the field of immunology and rheumatology, ACPAs may serve not only as a clinical marker but also as a therapeutic target for ACPA-positive RA patients with an erosive phenotype one day.

Funding: This work was supported by grants from the Ministry of Science and Technology (MOST 107-2314-B-182A-132-MY3 to Lai) and Chang Gung Memorial Hospital (CMRPG3J1901-2 and CMRPG3G1191 to Wu and CMRPG1H0101 to Lai), Taiwan, R.O.C.

Conflicts of Interest: The authors have no conflicts of interest related to this study.

$\begin{array}{ll}\text { Abbreviations } & \\ \text { Aa } & \text { Aggregatibacter actinomycetemcomitans } \\ \text { ACPA } & \text { anti-citrullinated protein antibody } \\ \text { APCs } & \text { antigen presenting cells } \\ \text { C5a } & \text { complement 5a } \\ \text { CCPs } & \text { cyclic citrullinated peptides } \\ \text { ERK } & \text { extracellular signal-regulated kinases } \\ \text { Fab } & \text { antigen-binding fragment } \\ \text { FC } & \text { crystallizable fragment } \\ \text { FC } \gamma \text { R } & \text { Fc gamma receptor } \\ \text { HLA } & \text { human leukocyte antigen } \\ \text { IC } & \text { immune complex } \\ \text { IFN } \gamma & \text { interferon-gamma } \\ \text { IL } & \text { Interleukin } \\ \text { JNK } & \text { c-Jun N-terminal kinase } \\ \text { MAC } & \text { membrane attack complex } \\ \text { MMPs } & \text { matrix metalloproteinases } \\ \text { NET } & \text { neutrophil extracellular trap } \\ \text { PAD } & \text { peptidyl arginine deiminase } \\ \text { P. gingivalis } & \text { Porphyromomas gingivalis } \\ \text { RA } & \text { rheumatoid arthritis } \\ \text { RF } & \text { rheumatoid factor } \\ \text { ROS } & \text { reactive oxygen species } \\ \text { SE } & \text { shared epitope } \\ \text { M-CSF } & \text { macrophage colony-stimulating factor } \\ \text { NF- } \text { B } & \text { nuclear factor-kappaB } \\ \text { RANKL } & \text { receptor activator of nuclear factor kappa-B ligand } \\ \text { TLR } & \text { Toll-like receptor } \\ \text { TNF- } \alpha & \text { tumor necrosis factor-alpha } \\ & \end{array}$




\section{References}

1. McInnes, I.B.; Schett, G. The pathogenesis of rheumatoid arthritis. N. Engl. J. Med. 2011, 365, $2205-2219$. [CrossRef] [PubMed]

2. Aletaha, D.; Neogi, T.; Silman, A.J.; Funovits, J.; Felson, D.T.; Bingham, C.O., III; Birnbaum, N.S.; Burmester, G.R.; Bykerk, V.P.; Cohen, M.D.; et al. 2010 Rheumatoid arthritis classification criteria: An American College of Rheumatology/European League Against Rheumatism collaborative initiative. Arthritis Rheum. 2010, 62, 2569-2581. [CrossRef] [PubMed]

3. Pinheiro, G.C.; Scheinberg, M.A.; Aparecida da Silva, M.; Maciel, S. Anti-cyclic citrullinated peptide antibodies in advanced rheumatoid arthritis. Ann. Intern. Med. 2003, 139, 234-235. [CrossRef] [PubMed]

4. Lee, D.M.; Schur, P.H. Clinical utility of the anti-CCP assay in patients with rheumatic diseases. Ann. Rheum. Dis. 2003, 62, 870-874. [CrossRef]

5. Van Zanten, A.; Arends, S.; Roozendaal, C.; Limburg, P.C.; Maas, F.; Trouw, L.A.; Toes, R.E.M.; Huizinga, T.W.J.; Bootsma, H.; Brouwer, E. Presence of anticitrullinated protein antibodies in a large population-based cohort from the Netherlands. Ann. Rheum. Dis. 2017, 76, 1184-1190. [CrossRef]

6. Van Beers, J.J.; Willemze, A.; Jansen, J.J.; Engbers, G.H.; Salden, M.; Raats, J.; Drijfhout, J.W.; van der Helm-van Mil, A.H.; Toes, R.E.; Pruijn, G.J. ACPA fine-specificity profiles in early rheumatoid arthritis patients do not correlate with clinical features at baseline or with disease progression. Arthritis Res. Ther. 2013, 15, R140. [CrossRef]

7. Schwenzer, A.; Jiang, X.; Mikuls, T.R.; Payne, J.B.; Sayles, H.R.; Quirke, A.M.; Kessler, B.M.; Fischer, R.; Venables, P.J.; Lundberg, K.; et al. Identification of an immunodominant peptide from citrullinated tenascin-C as a major target for autoantibodies in rheumatoid arthritis. Ann. Rheum. Dis. 2016, 75, 1876-1883. [CrossRef]

8. Johansson, L.; Pratesi, F.; Brink, M.; Arlestig, L.; D'Amato, C.; Bartaloni, D.; Migliorini, P.; Rantapaa-Dahlqvist, S. Antibodies directed against endogenous and exogenous citrullinated antigens pre-date the onset of rheumatoid arthritis. Arthritis Res. Ther. 2016, 18, 127. [CrossRef]

9. Vallbracht, I.; Rieber, J.; Oppermann, M.; Forger, F.; Siebert, U.; Helmke, K. Diagnostic and clinical value of anti-cyclic citrullinated peptide antibodies compared with rheumatoid factor isotypes in rheumatoid arthritis. Ann. Rheum. Dis. 2004, 63, 1079-1084. [CrossRef]

10. Visser, H.; le Cessie, S.; Vos, K.; Breedveld, F.C.; Hazes, J.M. How to diagnose rheumatoid arthritis early: A prediction model for persistent (erosive) arthritis. Arthritis Rheum. 2002, 46, 357-365. [CrossRef]

11. Kroot, E.J.; de Jong, B.A.; van Leeuwen, M.A.; Swinkels, H.; van den Hoogen, F.H.; van't Hof, M.; van de Putte, L.B.; van Rijswijk, M.H.; van Venrooij, W.J.; van Riel, P.L. The prognostic value of anti-cyclic citrullinated peptide antibody in patients with recent-onset rheumatoid arthritis. Arthritis Rheum. 2000, 43, 1831-1835. [CrossRef]

12. Nielen, M.M.; van Schaardenburg, D.; Reesink, H.W.; van de Stadt, R.J.; van der Horst-Bruinsma, I.E.; de Koning, M.H.; Habibuw, M.R.; Vandenbroucke, J.P.; Dijkmans, B.A. Specific autoantibodies precede the symptoms of rheumatoid arthritis: A study of serial measurements in blood donors. Arthritis Rheum. 2004, 50, 380-386. [CrossRef] [PubMed]

13. Koga, T.; Okada, A.; Fukuda, T.; Hidaka, T.; Ishii, T.; Ueki, Y.; Kodera, T.; Nakashima, M.; Takahashi, Y.; Honda, S.; et al. Anti-citrullinated peptide antibodies are the strongest predictor of clinically relevant radiographic progression in rheumatoid arthritis patients achieving remission or low disease activity: A post hoc analysis of a nationwide cohort in Japan. PLoS ONE 2017, 12, e0175281. [CrossRef] [PubMed]

14. Van den Broek, M.; Dirven, L.; Klarenbeek, N.B.; Molenaar, T.H.; Han, K.H.; Kerstens, P.J.; Huizinga, T.W.; Dijkmans, B.A.; Allaart, C.F. The association of treatment response and joint damage with ACPA-status in recent-onset RA: A subanalysis of the 8-year follow-up of the BeSt study. Ann. Rheum. Dis. 2012, 71, 245-248. [CrossRef]

15. Ajeganova, S.; Andersson, M.L.; Frostegard, J.; Hafstrom, I. Disease factors in early rheumatoid arthritis are associated with differential risks for cardiovascular events and mortality depending on age at onset: A 10-year observational cohort study. J. Rheumatol. 2013, 40, 1958-1966. [CrossRef]

16. Reynisdottir, G.; Karimi, R.; Joshua, V.; Olsen, H.; Hensvold, A.H.; Harju, A.; Engstrom, M.; Grunewald, J.; Nyren, S.; Eklund, A.; et al. Structural changes and antibody enrichment in the lungs are early features of anti-citrullinated protein antibody-positive rheumatoid arthritis. Arthritis Rheumatol. 2014, 66, 31-39. [CrossRef] 
17. Sellam, J.; Hendel-Chavez, H.; Rouanet, S.; Abbed, K.; Combe, B.; Le Loet, X.; Tebib, J.; Sibilia, J.; Taoufik, Y.; Dougados, M.; et al. B cell activation biomarkers as predictive factors for the response to rituximab in rheumatoid arthritis: A six-month, national, multicenter, open-label study. Arthritis Rheum. 2011, 63, 933-938. [CrossRef]

18. Isaacs, J.D.; Cohen, S.B.; Emery, P.; Tak, P.P.; Wang, J.; Lei, G.; Williams, S.; Lal, P.; Read, S.J. Effect of baseline rheumatoid factor and anticitrullinated peptide antibody serotype on rituximab clinical response: A meta-analysis. Ann. Rheum. Dis. 2013, 72, 329-336. [CrossRef]

19. Chatzidionysiou, K.; Lie, E.; Nasonov, E.; Lukina, G.; Hetland, M.L.; Tarp, U.; Gabay, C.; van Riel, P.L.; Nordstrom, D.C.; Gomez-Reino, J.; et al. Highest clinical effectiveness of rituximab in autoantibody-positive patients with rheumatoid arthritis and in those for whom no more than one previous TNF antagonist has failed: Pooled data from 10 European registries. Ann. Rheum. Dis. 2011, 70, 1575-1580. [CrossRef]

20. Ally, M.M.; Hodkinson, B.; Meyer, P.W.; Musenge, E.; Tintinger, G.R.; Tikly, M.; Anderson, R. Circulating anti-citrullinated peptide antibodies, cytokines and genotype as biomarkers of response to disease-modifying antirheumatic drug therapy in early rheumatoid arthritis. BMC Musculoskelet. Disord. 2015, 16, 130. [CrossRef]

21. Lv, Q.; Yin, Y.; Li, X.; Shan, G.; Wu, X.; Liang, D.; Li, Y.; Zhang, X. The status of rheumatoid factor and anti-cyclic citrullinated peptide antibody are not associated with the effect of anti-TNFalpha agent treatment in patients with rheumatoid arthritis: A meta-analysis. PLoS ONE 2014, 9, e89442. [CrossRef] [PubMed]

22. Pruijn, G.J.; Wiik, A.; van Venrooij, W.J. The use of citrullinated peptides and proteins for the diagnosis of rheumatoid arthritis. Arthritis Res. Ther. 2010, 12, 203. [CrossRef] [PubMed]

23. Valesini, G.; Gerardi, M.C.; Iannuccelli, C.; Pacucci, V.A.; Pendolino, M.; Shoenfeld, Y. Citrullination and autoimmunity. Autoimmun. Rev. 2015, 14, 490-497. [CrossRef] [PubMed]

24. Holers, V.M.; Demoruelle, M.K.; Kuhn, K.A.; Buckner, J.H.; Robinson, W.H.; Okamoto, Y.; Norris, J.M.; Deane, K.D. Rheumatoid arthritis and the mucosal origins hypothesis: Protection turns to destruction. Nat. Rev. Rheumatol. 2018, 14, 542-557. [CrossRef] [PubMed]

25. Malmstrom, V.; Catrina, A.I.; Klareskog, L. The immunopathogenesis of seropositive rheumatoid arthritis: From triggering to targeting. Nat. Rev. Immunol. 2017, 17, 60-75. [CrossRef]

26. Makrygiannakis, D.; Hermansson, M.; Ulfgren, A.K.; Nicholas, A.P.; Zendman, A.J.; Eklund, A.; Grunewald, J.; Skold, C.M.; Klareskog, L.; Catrina, A.I. Smoking increases peptidylarginine deiminase 2 enzyme expression in human lungs and increases citrullination in BAL cells. Ann. Rheum. Dis. 2008, 67, 1488-1492. [CrossRef]

27. Konig, M.F.; Andrade, F. A Critical Reappraisal of Neutrophil Extracellular Traps and NETosis Mimics Based on Differential Requirements for Protein Citrullination. Front. Immunol. 2016, 7, 461. [CrossRef]

28. Konig, M.F.; Abusleme, L.; Reinholdt, J.; Palmer, R.J.; Teles, R.P.; Sampson, K.; Rosen, A.; Nigrovic, P.A.; Sokolove, J.; Giles, J.T.; et al. Aggregatibacter actinomycetemcomitans-induced hypercitrullination links periodontal infection to autoimmunity in rheumatoid arthritis. Sci. Transl. Med. 2016, 8, 369ra176. [CrossRef]

29. Mukherjee, A.; Jantsch, V.; Khan, R.; Hartung, W.; Fischer, R.; Jantsch, J.; Ehrenstein, B.; Konig, M.F.; Andrade, F. Rheumatoid Arthritis-Associated Autoimmunity Due to Aggregatibacter actinomycetemcomitans and Its Resolution with Antibiotic Therapy. Front. Immunol. 2018, 9, 2352. [CrossRef]

30. Volkov, M.; van Schie, K.A.; van der Woude, D. Autoantibodies and B Cells: The ABC of rheumatoid arthritis pathophysiology. Immunol. Rev. 2020, 294, 148-163. [CrossRef]

31. Malmstrom, V.; Gronwall, C. The parallel worlds of ACPA-positive and RF-positive B cells. Nat. Rev. Rheumatol. 2018, 14, 626-628. [CrossRef] [PubMed]

32. Sokolove, J.; Zhao, X.; Chandra, P.E.; Robinson, W.H. Immune complexes containing citrullinated fibrinogen costimulate macrophages via Toll-like receptor 4 and Fcgamma receptor. Arthritis Rheum. 2011, 63, 53-62. [CrossRef] [PubMed]

33. Trouw, L.A.; Haisma, E.M.; Levarht, E.W.; van der Woude, D.; Ioan-Facsinay, A.; Daha, M.R.; Huizinga, T.W.; Toes, R.E. Anti-cyclic citrullinated peptide antibodies from rheumatoid arthritis patients activate complement via both the classical and alternative pathways. Arthritis Rheum. 2009, 60, 1923-1931. [CrossRef] [PubMed]

34. Rombouts, Y.; Ewing, E.; van de Stadt, L.A.; Selman, M.H.; Trouw, L.A.; Deelder, A.M.; Huizinga, T.W.; Wuhrer, M.; van Schaardenburg, D.; Toes, R.E.; et al. Anti-citrullinated protein antibodies acquire a pro-inflammatory Fc glycosylation phenotype prior to the onset of rheumatoid arthritis. Ann. Rheum. Dis 2015, 74, 234-241. [CrossRef] [PubMed] 
35. Arlestig, L.; Mullazehi, M.; Kokkonen, H.; Rocklov, J.; Ronnelid, J.; Dahlqvist, S.R. Antibodies against cyclic citrullinated peptides of IgG, IgA and IgM isotype and rheumatoid factor of IgM and IgA isotype are increased in unaffected members of multicase rheumatoid arthritis families from northern Sweden. Ann. Rheum. Dis. 2012, 71, 825-829. [CrossRef]

36. Engelmann, R.; Brandt, J.; Eggert, M.; Karberg, K.; Krause, A.; Neeck, G.; Mueller-Hilke, B. IgG1 and IgG4 are the predominant subclasses among auto-antibodies against two citrullinated antigens in RA. Rheumatology (Oxford) 2008, 47, 1489-1492. [CrossRef]

37. Willis, V.C.; Demoruelle, M.K.; Derber, L.A.; Chartier-Logan, C.J.; Parish, M.C.; Pedraza, I.F.; Weisman, M.H.; Norris, J.M.; Holers, V.M.; Deane, K.D. Sputum autoantibodies in patients with established rheumatoid arthritis and subjects at risk of future clinically apparent disease. Arthritis Rheum. 2013, 65, 2545-2554. [CrossRef]

38. Kokkonen, H.; Mullazehi, M.; Berglin, E.; Hallmans, G.; Wadell, G.; Ronnelid, J.; Rantapaa-Dahlqvist, S. Antibodies of IgG, IgA and IgM isotypes against cyclic citrullinated peptide precede the development of rheumatoid arthritis. Arthritis Res. Ther. 2011, 13, R13. [CrossRef]

39. Demoruelle, M.K.; Harrall, K.K.; Ho, L.; Purmalek, M.M.; Seto, N.L.; Rothfuss, H.M.; Weisman, M.H.; Solomon, J.J.; Fischer, A.; Okamoto, Y.; et al. Anti-Citrullinated Protein Antibodies Are Associated With Neutrophil Extracellular Traps in the Sputum in Relatives of Rheumatoid Arthritis Patients. Arthritis Rheum. 2017, 69, 1165-1175. [CrossRef]

40. Kinslow, J.D.; Blum, L.K.; Deane, K.D.; Demoruelle, M.K.; Okamoto, Y.; Parish, M.C.; Kongpachith, S.; Lahey, L.J.; Norris, J.M.; Robinson, W.H.; et al. Elevated IgA Plasmablast Levels in Subjects at Risk of Developing Rheumatoid Arthritis. Arthritis Rheum. 2016, 68, 2372-2383. [CrossRef]

41. Van der Steen, L.P.; Bakema, J.E.; Sesarman, A.; Florea, F.; Tuk, C.W.; Kirtschig, G.; Hage, J.J.; Sitaru, C.; van Egmond, M. Blocking Fcalpha receptor I on granulocytes prevents tissue damage induced by $\operatorname{IgA}$ autoantibodies. J. Immunol. 2012, 189, 1594-1601. [CrossRef] [PubMed]

42. Van Venrooij, W.J.; Pruijn, G.J. Citrullination: A small change for a protein with great consequences for rheumatoid arthritis. Arthritis Res. 2000, 2, 249-251. [CrossRef] [PubMed]

43. Fuhrmann, J.; Clancy, K.W.; Thompson, P.R. Chemical biology of protein arginine modifications in epigenetic regulation. Chem. Rev. 2015, 115, 5413-5461. [CrossRef]

44. Van Beers, J.J.; Schwarte, C.M.; Stammen-Vogelzangs, J.; Oosterink, E.; Bozic, B.; Pruijn, G.J. The rheumatoid arthritis synovial fluid citrullinome reveals novel citrullinated epitopes in apolipoprotein E, myeloid nuclear differentiation antigen, and beta-actin. Arthritis Rheum. 2013, 65, 69-80. [CrossRef] [PubMed]

45. Lee, C.Y.; Wang, D.; Wilhelm, M.; Zolg, D.P.; Schmidt, T.; Schnatbaum, K.; Reimer, U.; Ponten, F.; Uhlen, M.; Hahne, H.; et al. Mining the Human Tissue Proteome for Protein Citrullination. Mol. Cell Proteom. 2018, 17, 1378-1391. [CrossRef]

46. Wang, F.; Chen, F.F.; Gao, W.B.; Wang, H.Y.; Zhao, N.W.; Xu, M.; Gao, D.Y.; Yu, W.; Yan, X.L.; Zhao, J.N.; et al. Identification of citrullinated peptides in the synovial fluid of patients with rheumatoid arthritis using LC-MALDI-TOF/TOF. Clin. Rheumatol. 2016, 35, 2185-2194. [CrossRef]

47. Tilvawala, R.; Nguyen, S.H.; Maurais, A.J.; Nemmara, V.V.; Nagar, M.; Salinger, A.J.; Nagpal, S.; Weerapana, E.; Thompson, P.R. The Rheumatoid Arthritis-Associated Citrullinome. Cell Chem. Biol. 2018, 25, 691-770. [CrossRef]

48. Romero, V.; Fert-Bober, J.; Nigrovic, P.A.; Darrah, E.; Haque, U.J.; Lee, D.M.; van Eyk, J.; Rosen, A.; Andrade, F. Immune-mediated pore-forming pathways induce cellular hypercitrullination and generate citrullinated autoantigens in rheumatoid arthritis. Sci. Transl. Med. 2013, 5, 209ra150. [CrossRef]

49. Cambridge, G.; Leandro, M.J.; Lahey, L.J.; Fairhead, T.; Robinson, W.H.; Sokolove, J. B cell depletion with rituximab in patients with rheumatoid arthritis: Multiplex bead array reveals the kinetics of IgG and IgA antibodies to citrullinated antigens. J. Autoimmun. 2016, 70, 22-30. [CrossRef]

50. Kampstra, A.S.B.; Dekkers, J.S.; Volkov, M.; Dorjee, A.L.; Hafkenscheid, L.; Kempers, A.C.; van Delft, M.; Kissel, T.; Reijm, S.; Janssen, G.M.C.; et al. Different classes of anti-modified protein antibodies are induced on exposure to antigens expressing only one type of modification. Ann. Rheum. Dis. 2019, 78, 908-916. [CrossRef]

51. Shi, J.; Willemze, A.; Janssen, G.M.; van Veelen, P.A.; Drijfhout, J.W.; Cerami, A.; Huizinga, T.W.; Trouw, L.A.; Toes, R.E. Recognition of citrullinated and carbamylated proteins by human antibodies: Specificity, 
cross-reactivity and the 'AMC-Senshu' method. Ann. Rheum. Dis. 2013, 72, 148-150. [CrossRef] [PubMed]

52. Ge, C.; Holmdahl, R. The structure, specificity and function of anti-citrullinated protein antibodies. Nat. Rev. Rheumatol. 2019, 15, 503-508. [CrossRef] [PubMed]

53. Ge, C.; Xu, B.; Liang, B.; Lonnblom, E.; Lundstrom, S.L.; Zubarev, R.A.; Ayoglu, B.; Nilsson, P.; Skogh, T.; Kastbom, A.; et al. Structural Basis of Cross-Reactivity of Anti-Citrullinated Protein Antibodies. Arthritis Rheumatol. 2019, 71, 210-221. [CrossRef] [PubMed]

54. Ge, C.; Tong, D.; Liang, B.; Lonnblom, E.; Schneider, N.; Hagert, C.; Viljanen, J.; Ayoglu, B.; Stawikowska, R.; Nilsson, P.; et al. Anti-citrullinated protein antibodies cause arthritis by cross-reactivity to joint cartilage. JCI Insight 2017, 2. [CrossRef] [PubMed]

55. Van der Woude, D.; Rantapaa-Dahlqvist, S.; Ioan-Facsinay, A.; Onnekink, C.; Schwarte, C.M.; Verpoort, K.N.; Drijfhout, J.W.; Huizinga, T.W.; Toes, R.E.; Pruijn, G.J. Epitope spreading of the anti-citrullinated protein antibody response occurs before disease onset and is associated with the disease course of early arthritis. Ann. Rheum. Dis. 2010, 69, 1554-1561. [CrossRef] [PubMed]

56. Kongpachith, S.; Lingampalli, N.; Ju, C.H.; Blum, L.K.; Lu, D.R.; Elliott, S.E.; Mao, R.; Robinson, W.H. Affinity Maturation of the Anti-Citrullinated Protein Antibody Paratope Drives Epitope Spreading and Polyreactivity in Rheumatoid Arthritis. Arthritis Rheumatol. 2019, 71, 507-517. [CrossRef]

57. Titcombe, P.J.; Wigerblad, G.; Sippl, N.; Zhang, N.; Shmagel, A.K.; Sahlstrom, P.; Zhang, Y.; Barsness, L.O.; Ghodke-Puranik, Y.; Baharpoor, A.; et al. Pathogenic Citrulline-Multispecific B Cell Receptor Clades in Rheumatoid Arthritis. Arthritis Rheumatol. 2018, 70, 1933-1945. [CrossRef]

58. Elliott, S.E.; Kongpachith, S.; Lingampalli, N.; Adamska, J.Z.; Cannon, B.J.; Mao, R.; Blum, L.K.; Robinson, W.H. Affinity Maturation Drives Epitope Spreading and Generation of Proinflammatory Anti-Citrullinated Protein Antibodies in Rheumatoid Arthritis. Arthritis Rheumatol. 2018, 70, 1946-1958. [CrossRef]

59. Steen, J.; Forsstrom, B.; Sahlstrom, P.; Odowd, V.; Israelsson, L.; Krishnamurthy, A.; Badreh, S.; Mathsson Alm, L.; Compson, J.; Ramskold, D.; et al. Recognition of Amino Acid Motifs, Rather Than Specific Proteins, by Human Plasma Cell-Derived Monoclonal Antibodies to Posttranslationally Modified Proteins in Rheumatoid Arthritis. Arthritis Rheumatol. 2019, 71, 196-209. [CrossRef]

60. Lu, D.R.; McDavid, A.N.; Kongpachith, S.; Lingampalli, N.; Glanville, J.; Ju, C.H.; Gottardo, R.; Robinson, W.H. T Cell-Dependent Affinity Maturation and Innate Immune Pathways Differentially Drive Autoreactive B Cell Responses in Rheumatoid Arthritis. Arthritis Rheumatol. 2018, 70, 1732-1744. [CrossRef]

61. Imperiali, B.; O'Connor, S.E. Effect of N-linked glycosylation on glycopeptide and glycoprotein structure. Curr. Opin. Chem. Biol. 1999, 3, 643-649. [CrossRef]

62. Anumula, K.R. Quantitative glycan profiling of normal human plasma derived immunoglobulin and its fragments Fab and Fc. J. Immunol. Methods 2012, 382, 167-176. [CrossRef] [PubMed]

63. Vergroesen, R.D.; Slot, L.M.; Hafkenscheid, L.; Koning, M.T.; van der Voort, E.I.H.; Grooff, C.A.; Zervakis, G.; Veelken, H.; Huizinga, T.W.J.; Rispens, T.; et al. B-cell receptor sequencing of anti-citrullinated protein antibody (ACPA) IgG-expressing B cells indicates a selective advantage for the introduction of $\mathrm{N}$-glycosylation sites during somatic hypermutation. Ann. Rheum. Dis. 2018, 77, 956-958. [CrossRef] [PubMed]

64. Hafkenscheid, L.; Bondt, A.; Scherer, H.U.; Huizinga, T.W.; Wuhrer, M.; Toes, R.E.; Rombouts, Y. Structural Analysis of Variable Domain Glycosylation of Anti-Citrullinated Protein Antibodies in Rheumatoid Arthritis Reveals the Presence of Highly Sialylated Glycans. Mol. Cell Proteom. 2017, 16, 278-287. [CrossRef] [PubMed]

65. Hafkenscheid, L.; de Moel, E.; Smolik, I.; Tanner, S.; Meng, X.; Jansen, B.C.; Bondt, A.; Wuhrer, M.; Huizinga, T.W.J.; Toes, R.E.M.; et al. N-Linked Glycans in the Variable Domain of IgG Anti-Citrullinated Protein Antibodies Predict the Development of Rheumatoid Arthritis. Arthritis Rheumatol. 2019, 71, 1626-1633. [CrossRef]

66. Rombouts, Y.; Willemze, A.; van Beers, J.J.; Shi, J.; Kerkman, P.F.; van Toorn, L.; Janssen, G.M.; Zaldumbide, A.; Hoeben, R.C.; Pruijn, G.J.; et al. Extensive glycosylation of ACPA-IgG variable domains modulates binding to citrullinated antigens in rheumatoid arthritis. Ann. Rheum. Dis. 2016, 75, 578-585. [CrossRef]

67. Ohmi, Y.; Ise, W.; Harazono, A.; Takakura, D.; Fukuyama, H.; Baba, Y.; Narazaki, M.; Shoda, H.; Takahashi, N.; Ohkawa, Y.; et al. Sialylation converts arthritogenic IgG into inhibitors of collagen-induced arthritis. Nat. Commun. 2016, 7, 11205. [CrossRef] 
68. Lloyd, K.A.; Steen, J.; Amara, K.; Titcombe, P.J.; Israelsson, L.; Lundstrom, S.L.; Zhou, D.; Zubarev, R.A.; Reed, E.; Piccoli, L.; et al. Variable domain N-linked glycosylation and negative surface charge are key features of monoclonal ACPA: Implications for B-cell selection. Eur J. Immunol. 2018, 48, 1030-1045. [CrossRef]

69. Scherer, H.U.; van der Woude, D.; Ioan-Facsinay, A.; el Bannoudi, H.; Trouw, L.A.; Wang, J.; Haupl, T.; Burmester, G.R.; Deelder, A.M.; Huizinga, T.W.; et al. Glycan profiling of anti-citrullinated protein antibodies isolated from human serum and synovial fluid. Arthritis Rheum. 2010, 62, 1620-1629. [CrossRef]

70. Kaneko, Y.; Nimmerjahn, F.; Ravetch, J.V. Anti-inflammatory activity of immunoglobulin G resulting from FC sialylation. Science 2006, 313, 670-673. [CrossRef]

71. Rademacher, T.W.; Williams, P.; Dwek, R.A. Agalactosyl glycoforms of IgG autoantibodies are pathogenic. Proc. Natl. Acad. Sci. USA 1994, 91, 6123-6127. [CrossRef]

72. Anquetil, F.; Clavel, C.; Offer, G.; Serre, G.; Sebbag, M. IgM and IgA rheumatoid factors purified from rheumatoid arthritis sera boost the Fc receptor- and complement-dependent effector functions of the disease-specific anti-citrullinated protein autoantibodies. J. Immunol. 2015, 194, 3664-3674. [CrossRef]

73. Laurent, L.; Anquetil, F.; Clavel, C.; Ndongo-Thiam, N.; Offer, G.; Miossec, P.; Pasquali, J.L.; Sebbag, M.; Serre, G. IgM rheumatoid factor amplifies the inflammatory response of macrophages induced by the rheumatoid arthritis-specific immune complexes containing anticitrullinated protein antibodies. Ann. Rheum. Dis. 2015, 74, 1425-1431. [CrossRef] [PubMed]

74. Sokolove, J.; Johnson, D.S.; Lahey, L.J.; Wagner, C.A.; Cheng, D.; Thiele, G.M.; Michaud, K.; Sayles, H.; Reimold, A.M.; Caplan, L.; et al. Rheumatoid factor as a potentiator of anti-citrullinated protein antibody-mediated inflammation in rheumatoid arthritis. Arthritis Rheumatol. 2014, 66, 813-821. [CrossRef] [PubMed]

75. Yamakawa, M.; Ouhara, K.; Kajiya, M.; Munenaga, S.; Kittaka, M.; Yamasaki, S.; Takeda, K.; Takeshita, K.; Mizuno, N.; Fujita, T.; et al. Porphyromonas gingivalis infection exacerbates the onset of rheumatoid arthritis in SKG mice. Clin. Exp. Immunol. 2016, 186, 177-189. [CrossRef] [PubMed]

76. Arnoux, F.; Mariot, C.; Peen, E.; Lambert, N.C.; Balandraud, N.; Roudier, J.; Auger, I. Peptidyl arginine deiminase immunization induces anticitrullinated protein antibodies in mice with particular MHC types. Proc. Natl. Acad. Sci. USA 2017, 114, E10169-E10177. [CrossRef] [PubMed]

77. Witalison, E.E.; Thompson, P.R.; Hofseth, L.J. Protein Arginine Deiminases and Associated Citrullination: Physiological Functions and Diseases Associated with Dysregulation. Curr. Drug Targets 2015, 16, 700-710. [CrossRef]

78. Rogers, G.E.; Harding, H.W.; Llewellyn-Smith, I.J. The origin of citrulline-containing proteins in the hair follicle and the chemical nature of trichohyalin, an intracellular precursor. Biochim. Biophys Acta 1977, 495, 159-175. [CrossRef]

79. Fujisaki, M.; Sugawara, K. Properties of peptidylarginine deiminase from the epidermis of newborn rats. J. Biochem. 1981, 89, 257-263. [CrossRef]

80. Cuthbert, G.L.; Daujat, S.; Snowden, A.W.; Erdjument-Bromage, H.; Hagiwara, T.; Yamada, M.; Schneider, R.; Gregory, P.D.; Tempst, P.; Bannister, A.J.; et al. Histone deimination antagonizes arginine methylation. Cell 2004, 118, 545-553. [CrossRef]

81. Wang, Y.; Wysocka, J.; Sayegh, J.; Lee, Y.H.; Perlin, J.R.; Leonelli, L.; Sonbuchner, L.S.; McDonald, C.H.; Cook, R.G.; Dou, Y.; et al. Human PAD4 regulates histone arginine methylation levels via demethylimination. Science 2004, 306, 279-283. [CrossRef] [PubMed]

82. Tarcsa, E.; Marekov, L.N.; Mei, G.; Melino, G.; Lee, S.C.; Steinert, P.M. Protein unfolding by peptidylarginine deiminase. Substrate specificity and structural relationships of the natural substrates trichohyalin and filaggrin. J. Biol. Chem. 1996, 271, 30709-30716. [CrossRef] [PubMed]

83. Blachere, N.E.; Parveen, S.; Frank, M.O.; Dill, B.D.; Molina, H.; Orange, D.E. High-Titer Rheumatoid Arthritis Antibodies Preferentially Bind Fibrinogen Citrullinated by Peptidylarginine Deiminase 4. Arthritis Rheumatol. 2017, 69, 986-995. [CrossRef]

84. Foulquier, C.; Sebbag, M.; Clavel, C.; Chapuy-Regaud, S.; Al Badine, R.; Mechin, M.C.; Vincent, C.; Nachat, R.; Yamada, M.; Takahara, H.; et al. Peptidyl arginine deiminase type 2 (PAD-2) and PAD-4 but not PAD-1, PAD-3, and PAD-6 are expressed in rheumatoid arthritis synovium in close association with tissue inflammation. Arthritis Rheum. 2007, 56, 3541-3553. [CrossRef] 
85. Chang, X.; Yamada, R.; Suzuki, A.; Sawada, T.; Yoshino, S.; Tokuhiro, S.; Yamamoto, K. Localization of peptidylarginine deiminase 4 (PADI4) and citrullinated protein in synovial tissue of rheumatoid arthritis. Rheumatology 2005, 44, 40-50. [CrossRef] [PubMed]

86. Suzuki, A.; Yamada, R.; Chang, X.; Tokuhiro, S.; Sawada, T.; Suzuki, M.; Nagasaki, M.; Nakayama-Hamada, M.; Kawaida, R.; Ono, M.; et al. Functional haplotypes of PADI4, encoding citrullinating enzyme peptidylarginine deiminase 4, are associated with rheumatoid arthritis. Nat. Genet. 2003, 34, 395-402. [CrossRef]

87. Plenge, R.M.; Padyukov, L.; Remmers, E.F.; Purcell, S.; Lee, A.T.; Karlson, E.W.; Wolfe, F.; Kastner, D.L.; Alfredsson, L.; Altshuler, D.; et al. Replication of putative candidate-gene associations with rheumatoid arthritis in >4,000 samples from North America and Sweden: Association of susceptibility with PTPN22, CTLA4, and PADI4. Am. J. Hum. Genet. 2005, 77, 1044-1060. [CrossRef]

88. Ishikawa, Y.; Terao, C. The Impact of Cigarette Smoking on Risk of Rheumatoid Arthritis: A Narrative Review. Cells 2020, 9, 475. [CrossRef]

89. Kallberg, H.; Ding, B.; Padyukov, L.; Bengtsson, C.; Ronnelid, J.; Klareskog, L.; Alfredsson, L.; Group, E.S. Smoking is a major preventable risk factor for rheumatoid arthritis: Estimations of risks after various exposures to cigarette smoke. Ann. Rheum. Dis. 2011, 70, 508-511. [CrossRef]

90. Ishikawa, Y.; Ikari, K.; Hashimoto, M.; Ohmura, K.; Tanaka, M.; Ito, H.; Taniguchi, A.; Yamanaka, H.; Mimori, T.; Terao, C. Shared epitope defines distinct associations of cigarette smoking with levels of anticitrullinated protein antibody and rheumatoid factor. Ann. Rheum. Dis. 2019, 78, 1480-1487. [CrossRef]

91. Gomez-Banuelos, E.; Mukherjee, A.; Darrah, E.; Andrade, F. Rheumatoid Arthritis-Associated Mechanisms of Porphyromonas gingivalis and Aggregatibacter actinomycetemcomitans. J. Clin. Med. 2019, 8, 1309. [CrossRef]

92. Zhang, X.; Zhang, D.; Jia, H.; Feng, Q.; Wang, D.; Liang, D.; Wu, X.; Li, J.; Tang, L.; Li, Y.; et al. The oral and gut microbiomes are perturbed in rheumatoid arthritis and partly normalized after treatment. Nat. Med. 2015, 21, 895-905. [CrossRef]

93. Chen, J.; Wright, K.; Davis, J.M.; Jeraldo, P.; Marietta, E.V.; Murray, J.; Nelson, H.; Matteson, E.L.; Taneja, V. An expansion of rare lineage intestinal microbes characterizes rheumatoid arthritis. Genome. Med. 2016, 8, 43. [CrossRef]

94. Maeda, Y.; Kurakawa, T.; Umemoto, E.; Motooka, D.; Ito, Y.; Gotoh, K.; Hirota, K.; Matsushita, M.; Furuta, Y.; Narazaki, M.; et al. Dysbiosis Contributes to Arthritis Development via Activation of Autoreactive T Cells in the Intestine. Arthritis Rheumatol. 2016, 68, 2646-2661. [CrossRef] [PubMed]

95. Courbon, G.; Rinaudo-Gaujous, M.; Blasco-Baque, V.; Auger, I.; Caire, R.; Mijola, L.; Vico, L.; Paul, S.; Marotte, H. Porphyromonas gingivalis experimentally induces periodontis and an anti-CCP2-associated arthritis in the rat. Ann. Rheum. Dis. 2019, 78, 594-599. [CrossRef] [PubMed]

96. McGraw, W.T.; Potempa, J.; Farley, D.; Travis, J. Purification, characterization, and sequence analysis of a potential virulence factor from Porphyromonas gingivalis, peptidylarginine deiminase. Infect. Immun. 1999, 67, 3248-3256. [CrossRef] [PubMed]

97. De Aquino, S.G.; Talbot, J.; Sonego, F.; Turato, W.M.; Grespan, R.; Avila-Campos, M.J.; Cunha, F.Q.; Cirelli, J.A. The aggravation of arthritis by periodontitis is dependent of IL-17 receptor A activation. J. Clin. Periodontol. 2017, 44, 881-891. [CrossRef] [PubMed]

98. De Aquino, S.G.; Abdollahi-Roodsaz, S.; Koenders, M.I.; van de Loo, F.A.; Pruijn, G.J.; Marijnissen, R.J.; Walgreen, B.; Helsen, M.M.; van den Bersselaar, L.A.; de Molon, R.S.; et al. Periodontal pathogens directly promote autoimmune experimental arthritis by inducing a TLR2- and IL-1-driven Th17 response. J. Immunol. 2014, 192, 4103-4111. [CrossRef] [PubMed]

99. Spengler, J.; Lugonja, B.; Ytterberg, A.J.; Zubarev, R.A.; Creese, A.J.; Pearson, M.J.; Grant, M.M.; Milward, M.; Lundberg, K.; Buckley, C.D.; et al. Release of Active Peptidyl Arginine Deiminases by Neutrophils Can Explain Production of Extracellular Citrullinated Autoantigens in Rheumatoid Arthritis Synovial Fluid. Arthritis Rheumatol. 2015, 67, 3135-3145. [CrossRef]

100. Sorice, M.; Iannuccelli, C.; Manganelli, V.; Capozzi, A.; Alessandri, C.; Lococo, E.; Garofalo, T.; Di Franco, M.; Bombardieri, M.; Nerviani, A.; et al. Autophagy generates citrullinated peptides in human synoviocytes: A possible trigger for anti-citrullinated peptide antibodies. Rheumatology 2016, 55, 1374-1385. [CrossRef]

101. Khandpur, R.; Carmona-Rivera, C.; Vivekanandan-Giri, A.; Gizinski, A.; Yalavarthi, S.; Knight, J.S.; Friday, S.; Li, S.; Patel, R.M.; Subramanian, V.; et al. NETs are a source of citrullinated autoantigens and stimulate inflammatory responses in rheumatoid arthritis. Sci. Transl. Med. 2013, 5, 178ra140. [CrossRef] [PubMed] 
102. Sugawara, E.; Kato, M.; Kudo, Y.; Lee, W.; Hisada, R.; Fujieda, Y.; Oku, K.; Bohgaki, T.; Amengual, O.; Yasuda, S.; et al. Autophagy promotes citrullination of VIM (vimentin) and its interaction with major histocompatibility complex class II in synovial fibroblasts. Autophagy 2019, 16, 946-1955. [CrossRef] [PubMed]

103. Vomero, M.; Manganelli, V.; Barbati, C.; Colasanti, T.; Capozzi, A.; Finucci, A.; Spinelli, F.R.; Ceccarelli, F.; Perricone, C.; Truglia, S.; et al. Reduction of autophagy and increase in apoptosis correlates with a favorable clinical outcome in patients with rheumatoid arthritis treated with anti-TNF drugs. Arthritis Res. Ther. 2019, 21, 39. [CrossRef] [PubMed]

104. Carmona-Rivera, C.; Carlucci, P.M.; Moore, E.; Lingampalli, N.; Uchtenhagen, H.; James, E.; Liu, Y.; Bicker, K.L.; Wahamaa, H.; Hoffmann, V.; et al. Synovial fibroblast-neutrophil interactions promote pathogenic adaptive immunity in rheumatoid arthritis. Sci. Immunol. 2017, 2. [CrossRef]

105. Darrah, E.; Andrade, F. Rheumatoid arthritis and citrullination. Curr. Opin. Rheumatol. 2018, 30, $72-78$. [CrossRef]

106. Kinloch, A.; Lundberg, K.; Wait, R.; Wegner, N.; Lim, N.H.; Zendman, A.J.; Saxne, T.; Malmstrom, V.; Venables, P.J. Synovial fluid is a site of citrullination of autoantigens in inflammatory arthritis. Arthritis Rheum. 2008, 58, 2287-2295. [CrossRef]

107. Nakayama-Hamada, M.; Suzuki, A.; Kubota, K.; Takazawa, T.; Ohsaka, M.; Kawaida, R.; Ono, M.; Kasuya, A.; Furukawa, H.; Yamada, R.; et al. Comparison of enzymatic properties between hPADI2 and hPADI4. Biochem. Biophys Res. Commun. 2005, 327, 192-200. [CrossRef]

108. Kinne, R.W.; Brauer, R.; Stuhlmuller, B.; Palombo-Kinne, E.; Burmester, G.R. Macrophages in rheumatoid arthritis. Arthritis Res. 2000, 2, 189-202. [CrossRef]

109. Lu, M.C.; Lai, N.S.; Yu, H.C.; Huang, H.B.; Hsieh, S.C.; Yu, C.L. Anti-citrullinated protein antibodies bind surface-expressed citrullinated Grp78 on monocyte/macrophages and stimulate tumor necrosis factor alpha production. Arthritis Rheum. 2010, 62, 1213-1223. [CrossRef]

110. Lu, M.C.; Lai, N.S.; Yin, W.Y.; Yu, H.C.; Huang, H.B.; Tung, C.H.; Huang, K.Y.; Yu, C.L. Anti-citrullinated protein antibodies activated ERK1/2 and JNK mitogen-activated protein kinases via binding to surface-expressed citrullinated GRP78 on mononuclear cells. J. Clin. Immunol. 2013, 33, 558-566. [CrossRef]

111. Lai, N.S.; Yu, H.C.; Yu, C.L.; Koo, M.; Huang, H.B.; Lu, M.C. Anti-citrullinated protein antibodies suppress let-7a expression in monocytes from patients with rheumatoid arthritis and facilitate the inflammatory responses in rheumatoid arthritis. Immunobiology 2015, 220, 1351-1358. [CrossRef] [PubMed]

112. Clavel, C.; Nogueira, L.; Laurent, L.; Iobagiu, C.; Vincent, C.; Sebbag, M.; Serre, G. Induction of macrophage secretion of tumor necrosis factor alpha through Fcgamma receptor IIa engagement by rheumatoid arthritis-specific autoantibodies to citrullinated proteins complexed with fibrinogen. Arthritis Rheum. 2008, 58, 678-688. [CrossRef] [PubMed]

113. Clavel, C.; Ceccato, L.; Anquetil, F.; Serre, G.; Sebbag, M. Among human macrophages polarised to different phenotypes, the M-CSF-oriented cells present the highest pro-inflammatory response to the rheumatoid arthritis-specific immune complexes containing ACPA. Ann. Rheum. Dis. 2016, 75, 2184-2191. [CrossRef] [PubMed]

114. Farrugia, M.; Baron, B. The role of TNF-alpha in rheumatoid arthritis: A focus on regulatory T cells. J. Clin. Transl. Res. 2016, 2, 84-90. [CrossRef]

115. Nurcombe, H.L.; Bucknall, R.C.; Edwards, S.W. Neutrophils isolated from the synovial fluid of patients with rheumatoid arthritis: Priming and activation in vivo. Ann. Rheum. Dis. 1991, 50, 147-153. [CrossRef]

116. Watson, F.; Robinson, J.J.; Phelan, M.; Bucknall, R.C.; Edwards, S.W. Receptor expression in synovial fluid neutrophils from patients with rheumatoid arthritis. Ann. Rheum. Dis. 1993, 52, 354-359. [CrossRef]

117. Quayle, J.A.; Watson, F.; Bucknall, R.C.; Edwards, S.W. Neutrophils from the synovial fluid of patients with rheumatoid arthritis express the high affinity immunoglobulin G receptor, Fc gamma RI (CD64): Role of immune complexes and cytokines in induction of receptor expression. Immunology 1997, 91, 266-273. [CrossRef]

118. Robinson, J.J.; Watson, F.; Bucknall, R.C.; Edwards, S.W. Role of Fc gamma receptors in the activation of neutrophils by soluble and insoluble immunoglobulin aggregates isolated from the synovial fluid of patients with rheumatoid arthritis. Ann. Rheum. Dis. 1994, 53, 515-520. [CrossRef]

119. Kempers, A.C.; Nejadnik, M.R.; Rombouts, Y.; Ioan-Facsinay, A.; van Oosterhout, M.; Jiskoot, W.; Huizinga, T.W.J.; Toes, R.E.M.; Scherer, H.U. Fc gamma receptor binding profile of anti-citrullinated 
protein antibodies in immune complexes suggests a role for FcgammaRI in the pathogenesis of synovial inflammation. Clin. Exp. Rheumatol. 2018, 36, 284-293.

120. Wright, H.L.; Moots, R.J.; Edwards, S.W. The multifactorial role of neutrophils in rheumatoid arthritis. Nat. Rev. Rheumatol. 2014, 10, 593-601. [CrossRef]

121. Chirivi, R.G.S.; van Rosmalen, J.W.G.; van der Linden, M.; Euler, M.; Schmets, G.; Bogatkevich, G.; Kambas, K.; Hahn, J.; Braster, Q.; Soehnlein, O.; et al. Therapeutic ACPA inhibits NET formation: A potential therapy for neutrophil-mediated inflammatory diseases. Cell Mol. Immunol. 2020, 1-17. [CrossRef] [PubMed]

122. Corsiero, E.; Bombardieri, M.; Carlotti, E.; Pratesi, F.; Robinson, W.; Migliorini, P.; Pitzalis, C. Single cell cloning and recombinant monoclonal antibodies generation from RA synovial B cells reveal frequent targeting of citrullinated histones of NETs. Ann. Rheum. Dis. 2016, 75, 1866-1875. [CrossRef] [PubMed]

123. Lloyd, K.A.; Wigerblad, G.; Sahlstrom, P.; Garimella, M.G.; Chemin, K.; Steen, J.; Titcombe, P.J.; Marklein, B.; Zhou, D.; Stalesen, R.; et al. Differential ACPA Binding to Nuclear Antigens Reveals a PAD-Independent Pathway and a Distinct Subset of Acetylation Cross-Reactive Autoantibodies in Rheumatoid Arthritis. Front. Immunol. 2018, 9, 3033. [CrossRef] [PubMed]

124. Holers, V.M.; Banda, N.K. Complement in the Initiation and Evolution of Rheumatoid Arthritis. Front. Immunol. 2018, 9, 1057. [CrossRef]

125. Di Muzio, G.; Perricone, C.; Ballanti, E.; Kroegler, B.; Greco, E.; Novelli, L.; Conigliaro, P.; Cipriani, P.; Giacomelli, R.; Perricone, R. Complement system and rheumatoid arthritis: Relationships with autoantibodies, serological, clinical features, and anti-TNF treatment. Int. J. Immunopathol. Pharmacol. 2011, 24, 357-366. [CrossRef]

126. Sacks, T.; Moldow, C.F.; Craddock, P.R.; Bowers, T.K.; Jacob, H.S. Oxygen radicals mediate endothelial cell damage by complement-stimulated granulocytes. An in vitro model of immune vascular damage. J. Clin. Invest. 1978, 61, 1161-1167. [CrossRef]

127. Shushakova, N.; Skokowa, J.; Schulman, J.; Baumann, U.; Zwirner, J.; Schmidt, R.E.; Gessner, J.E. C5a anaphylatoxin is a major regulator of activating versus inhibitory FcgammaRs in immune complex-induced lung disease. J. Clin. Invest. 2002, 110, 1823-1830. [CrossRef]

128. Tsuboi, N.; Ernandez, T.; Li, X.; Nishi, H.; Cullere, X.; Mekala, D.; Hazen, M.; Kohl, J.; Lee, D.M.; Mayadas, T.N. Regulation of human neutrophil Fcgamma receptor IIa by $\mathrm{C} 5$ a receptor promotes inflammatory arthritis in mice. Arthritis Rheum. 2011, 63, 467-478. [CrossRef]

129. Aarvak, T.; Natvig, J.B. Cell-cell interactions in synovitis: Antigen presenting cells and T cell interaction in rheumatoid arthritis. Arthritis Res. 2001, 3, 13-17. [CrossRef]

130. Takemura, S.; Braun, A.; Crowson, C.; Kurtin, P.J.; Cofield, R.H.; O’Fallon, W.M.; Goronzy, J.J.; Weyand, C.M. Lymphoid neogenesis in rheumatoid synovitis. J. Immunol. 2001, 167, 1072-1080. [CrossRef]

131. Kerkman, P.F.; Kempers, A.C.; van der Voort, E.I.; van Oosterhout, M.; Huizinga, T.W.; Toes, R.E.; Scherer, H.U. Synovial fluid mononuclear cells provide an environment for long-term survival of antibody-secreting cells and promote the spontaneous production of anti-citrullinated protein antibodies. Ann. Rheum. Dis. 2016, 75, 2201-2207. [CrossRef] [PubMed]

132. Humby, F.; Bombardieri, M.; Manzo, A.; Kelly, S.; Blades, M.C.; Kirkham, B.; Spencer, J.; Pitzalis, C. Ectopic lymphoid structures support ongoing production of class-switched autoantibodies in rheumatoid synovium. PLoS Med. 2009, 6, e1. [CrossRef]

133. Takemura, S.; Klimiuk, P.A.; Braun, A.; Goronzy, J.J.; Weyand, C.M. T cell activation in rheumatoid synovium is B cell dependent. J. Immunol. 2001, 167, 4710-4718. [CrossRef] [PubMed]

134. James, E.A.; Rieck, M.; Pieper, J.; Gebe, J.A.; Yue, B.B.; Tatum, M.; Peda, M.; Sandin, C.; Klareskog, L.; Malmstrom, V.; et al. Citrulline-specific Th1 cells are increased in rheumatoid arthritis and their frequency is influenced by disease duration and therapy. Arthritis Rheumatol. 2014, 66, 1712-1722. [CrossRef] [PubMed]

135. Snir, O.; Rieck, M.; Gebe, J.A.; Yue, B.B.; Rawlings, C.A.; Nepom, G.; Malmstrom, V.; Buckner, J.H. Identification and functional characterization of $\mathrm{T}$ cells reactive to citrullinated vimentin in HLA-DRB1*0401-positive humanized mice and rheumatoid arthritis patients. Arthritis Rheum. 2011, 63, 2873-2883. [CrossRef] [PubMed]

136. Meednu, N.; Zhang, H.; Owen, T.; Sun, W.; Wang, V.; Cistrone, C.; Rangel-Moreno, J.; Xing, L.; Anolik, J.H. Production of RANKL by Memory B Cells: A Link Between B Cells and Bone Erosion in Rheumatoid Arthritis. Arthritis Rheumatol. 2016, 68, 805-816. [CrossRef]

137. Cope, A.P. T cells in rheumatoid arthritis. Arthritis Res. Ther. 2008, 10, S1. [CrossRef] 
138. Gaffen, S.L. The role of interleukin-17 in the pathogenesis of rheumatoid arthritis. Curr. Rheumatol. Rep. 2009, 11, 365-370. [CrossRef]

139. Ehrhardt, G.R.; Hijikata, A.; Kitamura, H.; Ohara, O.; Wang, J.Y.; Cooper, M.D. Discriminating gene expression profiles of memory B cell subpopulations. J. Exp. Med. 2008, 205, 1807-1817. [CrossRef]

140. Pistoia, V. Production of cytokines by human B cells in health and disease. Immunol. Today 1997, 18, 343-350. [CrossRef]

141. Harre, U.; Georgess, D.; Bang, H.; Bozec, A.; Axmann, R.; Ossipova, E.; Jakobsson, P.J.; Baum, W.; Nimmerjahn, F.; Szarka, E.; et al. Induction of osteoclastogenesis and bone loss by human autoantibodies against citrullinated vimentin. J. Clin. Invest. 2012, 122, 1791-1802. [CrossRef] [PubMed]

142. Krishnamurthy, A.; Joshua, V.; Haj Hensvold, A.; Jin, T.; Sun, M.; Vivar, N.; Ytterberg, A.J.; Engstrom, M.; Fernandes-Cerqueira, C.; Amara, K.; et al. Identification of a novel chemokine-dependent molecular mechanism underlying rheumatoid arthritis-associated autoantibody-mediated bone loss. Ann. Rheum. Dis. 2016, 75, 721-729. [CrossRef] [PubMed]

143. Wigerblad, G.; Bas, D.B.; Fernades-Cerqueira, C.; Krishnamurthy, A.; Nandakumar, K.S.; Rogoz, K.; Kato, J.; Sandor, K.; Su, J.; Jimenez-Andrade, J.M.; et al. Autoantibodies to citrullinated proteins induce joint pain independent of inflammation via a chemokine-dependent mechanism. Ann. Rheum. Dis. 2016, 75, 730-738. [CrossRef]

144. Amara, K.; Steen, J.; Murray, F.; Morbach, H.; Fernandez-Rodriguez, B.M.; Joshua, V.; Engstrom, M.; Snir, O.; Israelsson, L.; Catrina, A.I.; et al. Retraction: Monoclonal IgG antibodies generated from joint-derived B cells of RA patients have a strong bias toward citrullinated autoantigen recognition. J. Exp. Med. 2019, 216, 245. [CrossRef] [PubMed]

145. Correction: Autoantibodies to citrullinated proteins induce joint pain independent of inflammation via a chemokine-dependent mechanism. Ann. Rheum. Dis. 2019, 78, 865. [CrossRef] [PubMed]

146. Correction: Identification of a novel chemokine-dependent molecular mechanism underlying rheumatoid arthritis-associated autoantibody-mediated bone loss. Ann. Rheum. Dis. 2019, 78, 866. [CrossRef] [PubMed]

147. Toes, R.; Pisetsky, D.S. Pathogenic effector functions of ACPA: Where do we stand? Ann. Rheum. Dis. 2019, 78, 716-721. [CrossRef]

148. Holmdahl, R. Comment on editorial 'Pathogenic effector functions of ACPA: where do we stand? ' Ann. Rheum. Dis. 2019. [CrossRef]

149. Sun, M.; Rethi, B.; Krishnamurthy, A.; Joshua, V.; Circiumaru, A.; Hensvold, A.H.; Ossipova, E.; Gronwall, C.; Liu, Y.; Engstrom, M.; et al. Anticitrullinated protein antibodies facilitate migration of synovial tissue-derived fibroblasts. Ann. Rheum. Dis. 2019, 78, 1621-1631. [CrossRef]

150. Humphrey, M.B.; Nakamura, M.C. A Comprehensive Review of Immunoreceptor Regulation of Osteoclasts. Clin. Rev. Allergy Immunol. 2016, 51, 48-58. [CrossRef]

151. Mocsai, A.; Humphrey, M.B.; Van Ziffle, J.A.; Hu, Y.; Burghardt, A.; Spusta, S.C.; Majumdar, S.; Lanier, L.L.; Lowell, C.A.; Nakamura, M.C. The immunomodulatory adapter proteins DAP12 and FC receptor gamma-chain (FcRgamma) regulate development of functional osteoclasts through the Syk tyrosine kinase. Proc. Natl. Acad. Sci. USA 2004, 101, 6158-6163. [CrossRef] [PubMed]

152. Grevers, L.C.; de Vries, T.J.; Everts, V.; Verbeek, J.S.; van den Berg, W.B.; van Lent, P.L. Immune complex-induced inhibition of osteoclastogenesis is mediated via activating but not inhibitory Fcgamma receptors on myeloid precursor cells. Ann. Rheum. Dis. 2013, 72, 278-285. [CrossRef]

153. Seeling, M.; Hillenhoff, U.; David, J.P.; Schett, G.; Tuckermann, J.; Lux, A.; Nimmerjahn, F. Inflammatory monocytes and Fcgamma receptor IV on osteoclasts are critical for bone destruction during inflammatory arthritis in mice. Proc. Natl. Acad. Sci. USA 2013, 110, 10729-10734. [CrossRef] [PubMed]

154. Harre, U.; Lang, S.C.; Pfeifle, R.; Rombouts, Y.; Fruhbeisser, S.; Amara, K.; Bang, H.; Lux, A.; Koeleman, C.A.; Baum, W.; et al. Glycosylation of immunoglobulin G determines osteoclast differentiation and bone loss. Nat. Commun. 2015, 6, 6651. [CrossRef]

155. Hecht, C.; Englbrecht, M.; Rech, J.; Schmidt, S.; Araujo, E.; Engelke, K.; Finzel, S.; Schett, G. Additive effect of anti-citrullinated protein antibodies and rheumatoid factor on bone erosions in patients with RA. Ann. Rheum. Dis. 2015, 74, 2151-2156. [CrossRef] [PubMed]

156. Bugatti, S.; Bogliolo, L.; Vitolo, B.; Manzo, A.; Montecucco, C.; Caporali, R. Anti-citrullinated protein antibodies and high levels of rheumatoid factor are associated with systemic bone loss in patients with early untreated rheumatoid arthritis. Arthritis Res. Ther. 2016, 18, 226. [CrossRef] 
157. Yoshitomi, H. Regulation of Immune Responses and Chronic Inflammation by Fibroblast-Like Synoviocytes. Front. Immunol. 2019, 10, 1395. [CrossRef] [PubMed]

158. Corsiero, E.; Jagemann, L.; Perretti, M.; Pitzalis, C.; Bombardieri, M. Characterization of a Synovial B Cell-Derived Recombinant Monoclonal Antibody Targeting Stromal Calreticulin in the Rheumatoid Joints. J. Immunol. 2018, 201, 1373-1381. [CrossRef] [PubMed]

159. Buckwalter, J.A.; Mankin, H.J. Articular cartilage: Tissue design and chondrocyte-matrix interactions. Instr. Course. Lect. 1998, 47, 477-486. [PubMed]

160. Beard, H.K.; Ryvar, R.; Skingle, J.; Greenbury, C.L. Anti-collagen antibodies in sera from rheumatoid arthritis patients. J. Clin. Pathol. 1980, 33, 1077-1081. [CrossRef]

161. Cooke, T.D.; Hurd, E.R.; Jasin, H.E.; Bienenstock, J.; Ziff, M. Identification of immunoglobulins and complement in rheumatoid articular collagenous tissues. Arthritis Rheum. 1975, 18, 541-551. [CrossRef] [PubMed]

162. Smolen, J.S.; Landewe, R.B.M.; Bijlsma, J.W.J.; Burmester, G.R.; Dougados, M.; Kerschbaumer, A.; McInnes, I.B.; Sepriano, A.; van Vollenhoven, R.F.; de Wit, M.; et al. EULAR recommendations for the management of rheumatoid arthritis with synthetic and biological disease-modifying antirheumatic drugs: 2019 update. Ann. Rheum. Dis. 2020. [CrossRef] [PubMed]

163. Lorenzetti, R.; Janowska, I.; Smulski, C.R.; Frede, N.; Henneberger, N.; Walter, L.; Schleyer, M.T.; Huppe, J.M.; Staniek, J.; Salzer, U.; et al. Abatacept modulates CD80 and CD86 expression and memory formation in human B-cells. J. Autoimmun. 2019, 101, 145-152. [CrossRef] [PubMed]

164. Bohler, C.; Radner, H.; Smolen, J.S.; Aletaha, D. Serological changes in the course of traditional and biological disease modifying therapy of rheumatoid arthritis. Ann. Rheum. Dis. 2013, 72, 241-244. [CrossRef]

165. Cambridge, G.; Perry, H.C.; Nogueira, L.; Serre, G.; Parsons, H.M.; De La Torre, I.; Dickson, M.C.; Leandro, M.J.; Edwards, J.C. The effect of B-cell depletion therapy on serological evidence of B-cell and plasmablast activation in patients with rheumatoid arthritis over multiple cycles of rituximab treatment. J. Autoimmun. 2014, 50, 67-76. [CrossRef]

166. Bugatti, S.; Manzo, A.; Montecucco, C.; Caporali, R. The Clinical Value of Autoantibodies in Rheumatoid Arthritis. Front. Med. (Lausanne) 2018, 5, 339. [CrossRef]

167. Benham, H.; Nel, H.J.; Law, S.C.; Mehdi, A.M.; Street, S.; Ramnoruth, N.; Pahau, H.; Lee, B.T.; Ng, J.; Brunck, M.E.; et al. Citrullinated peptide dendritic cell immunotherapy in HLA risk genotype-positive rheumatoid arthritis patients. Sci. Transl. Med. 2015, 7, 290ra287. [CrossRef]

168. Wang, X.; Xia, Y. Anti-double Stranded DNA Antibodies: Origin, Pathogenicity, and Targeted Therapies. Front. Immunol. 2019, 10, 1667. [CrossRef]

169. Gesheva, V.; Kerekov, N.; Nikolova, K.; Mihaylova, N.; Todorov, T.; Nikolova, M.; Tchorbanov, A. Suppression of dsDNA-specific B lymphocytes reduces disease symptoms in SCID model of mouse lupus. Autoimmunity 2014, 47, 162-172. [CrossRef]

170. Sthoeger, Z.; Sharabi, A.; Mozes, E. Novel approaches to the development of targeted therapeutic agents for systemic lupus erythematosus. J. Autoimmun. 2014, 54, 60-71. [CrossRef]

171. Fernandes-Cerqueira, C.; Ossipova, E.; Gunasekera, S.; Hansson, M.; Mathsson, L.; Catrina, A.I.; Sommarin, Y.; Klareskog, L.; Lundberg, K.; Ronnelid, J.; et al. Targeting of anti-citrullinated protein/peptide antibodies in rheumatoid arthritis using peptides mimicking endogenously citrullinated fibrinogen antigens. Arthritis Res. Ther. 2015, 17, 155. [CrossRef] [PubMed]

172. Gunasekera, S.; Fernandes-Cerqueira, C.; Wennmalm, S.; Wahamaa, H.; Sommarin, Y.; Catrina, A.I.; Jakobsson, P.J.; Goransson, U. Stabilized Cyclic Peptides as Scavengers of Autoantibodies: Neutralization of Anticitrullinated Protein/Peptide Antibodies in Rheumatoid Arthritis. ACS Chem. Biol. 2018, 13, 1525-1535. [CrossRef] [PubMed]

173. Willis, V.C.; Gizinski, A.M.; Banda, N.K.; Causey, C.P.; Knuckley, B.; Cordova, K.N.; Luo, Y.; Levitt, B.; Glogowska, M.; Chandra, P.; et al. N-alpha-benzoyl-N5-(2-chloro-1-iminoethyl)-L-ornithine amide, a protein arginine deiminase inhibitor, reduces the severity of murine collagen-induced arthritis. J. Immunol. 2011, 186, 4396-4404. [CrossRef] [PubMed]

174. Aliko, A.; Kaminska, M.; Falkowski, K.; Bielecka, E.; Benedyk-Machaczka, M.; Malicki, S.; Koziel, J.; Wong, A.; Bryzek, D.; Kantyka, T.; et al. Discovery of Novel Potential Reversible Peptidyl Arginine Deiminase Inhibitor. Int. J. Mol. Sci. USA 2019, 20, 2174. [CrossRef] [PubMed] 
175. Reily, C.; Stewart, T.J.; Renfrow, M.B.; Novak, J. Glycosylation in health and disease. Nat. Rev. Nephrol. 2019, 15, 346-366. [CrossRef] [PubMed]

176. Crivianu-Gaita, V.; Thompson, M. Aptamers, antibody scFv, and antibody Fab' fragments: An overview and comparison of three of the most versatile biosensor biorecognition elements. Biosens. Bioelectron. 2016, 85, 32-45. [CrossRef]

177. Hair, P.S.; Enos, A.I.; Krishna, N.K.; Cunnion, K.M. Inhibition of Immune Complex Complement Activation and Neutrophil Extracellular Trap Formation by Peptide Inhibitor of Complement C1. Front. Immunol. 2018, 9, 558. [CrossRef]

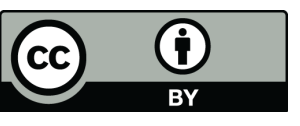

(C) 2020 by the authors. Licensee MDPI, Basel, Switzerland. This article is an open access article distributed under the terms and conditions of the Creative Commons Attribution (CC BY) license (http://creativecommons.org/licenses/by/4.0/). 